Marcia C. Schenck, Immanuel R. Harisch, Anne Dietrich, and Eric Burton ${ }^{1}$

\title{
1 Introduction: Moorings and (Dis)Entanglements between Africa and East Germany during the Cold War
}

The Arusha Declaration of February 5, 1967 confirmed the intention of Tanzania's ruling party TANU (Tanganyika African National Union) to "build a socialist state." 2 The declaration affirmed that TANU planned to pursue a policy of nationalization of major industries, banks, and insurance companies. ${ }^{3}$ Two months after the declaration, the Tanzanian trade unionist Salvatory Kaindoah wrote an enthusiastic letter to share the news of developments in his country with the Fritz Heckert Trade Union College, in the East German town of Bernau where Kaindoah had studied:

Dear Director of the College, Dr. Kampfert,

I am very glad when I am writing this letter to you now, being in a country which is in a way liquidating the exploitation of man by man and on the way to Socialism. Well done with your daily work. How glad were you, when you heard that our country nationalized all the banks and other big industries? ${ }^{4}$

Kaindoah, at that time employed at the Tanzanian National Institute for Productivity in Dar es Salaam, seemed to suggest that the Arusha Declaration meant the

1 This introduction is the result of a collective thinking and writing process of all four editors. Given the ongoing benchmarkization of current academia, it is of increasing importance which author's name comes first. In order to mitigate the effects of this development, we have decided to use an alphabetical order for the edited volume and an alphabetically reversed order for the introduction. The introduction also owes much to the valuable comments, corrections, and advice of a number of people. We want to thank the two anonymous reviewers, Nele Fabian, Ingeborg Grau, and Arno Sonderegger for their careful reading and helpful suggestions. We also want to thank the members of the GDR working group at Leipzig University and Innocent Rwehabura for their comments. Last but not least we are grateful to Pieter Cordwell for skillfully editing the text and to Malte Köppen for streamlining the footnotes, cleaning up the bibliography, and creating the index.

2 Tanganyika African National Union, “Arusha Declaration,” February 5, 1967, accessed January 29, 2020, www.marxists.org/subject/africa/nyerere/1967/arusha-declaration.htm.

3 Andrew Coulson, Tanzania: A Political Economy (Oxford: Oxford University Press, 2013).

4 Salvatory Kaindoah to Karl Kampfert, Dar es Salaam, April 10, 1967, Stiftung Archiv der Parteien und Massenorganisationen der DDR im Bundesarchiv, Berlin (henceforth: SAPMO BArch), DY 79/619.

Ә OpenAccess. () 2021 Marcia C. Schenck, Immanuel R. Harisch, Anne Dietrich, and Eric Burton, published by De Gruyter. (cc) BY This work is licensed under the Creative Commons Attribution 4.0 International License. https://doi.org/10.1515/9783110623543-001 
convergence of the United Republic of Tanzania with the German Democratic Republic (GDR) in a cohesive and growing world of socialism. This was to be Socialism with a capital "S," perhaps optimistically indicating that the policies of TANU and the policies of the GDR's ruling Socialist Unity Party (Sozialistische Einheitspartei Deutschlands, SED) led to a shared socialist future. Kaindoah's celebratory letter is one of a myriad of examples of dialogue and entanglements between African proponents of socialism, with their multiple visions of African and global futures, and East German individuals and institutions.

Many East Germans, however, were less confident about the viability of Tanzania's policies and converging paths - including those who observed these events from East Africa. Some weeks before Kaindoah's letter was written, East German experts and diplomats gathered at a meeting of the local party branch of the SED in Stone Town, the capital of Tanzania's island region of Zanzibar (it had been a separate country until it merged with Tanganyika in 1964 to create Tanzania). Their discussions revealed the urge to classify and evaluate the Arusha Declaration based on how it conformed to Marxist-Leninist dogma. According to the minutes of the party meeting, several comrades "immediately labeled the program as unscientific" and dismissed its usefulness to building socialism in Tanzania. Other members questioned the suitability of a socialist program to Tanzania. They saw Tanzania as being completely different in material and cultural terms compared to European circumstances, and at least one developmental stage away from being a "Workers' and Peasants' State," like the GDR. One member asserted that the Arusha Declaration was "based on the level of development and the mentality of Africans. Can Africans even build socialism with their ideology?" He further alluded to the fact that the East Germans had not seen the declaration coming, despite their supposedly leading role in guiding Tanzania to socialism: "Why were we surprised by the declaration?"5 The surprise felt by the East Germans in Zanzibar stemmed from the fact that many of them took for granted the leading roles of the Soviet Union and the GDR on the road to socialist development. Thus, many found it difficult to come to terms with Tanzanian actors who were conceptualizing their own road to socialist development.

In both Tanzania and the GDR, socialism would remain official government policy for the next two decades and beyond. By 1967, both socialisms had al-

5 Contribution by Comrade O., no place [Zanzibar], no date [March 9, 1967], SAPMO-BArch, DY 30/98149. For a discussion of the role of East German advisers in Zanzibar, see Eric Burton, "Diverging Visions in Revolutionary Spaces: East German Advisers and Revolution from Above in Zanzibar, 1964-1970," in Between East and South: Spaces of Interaction in the Globalizing Economy of the Cold War, ed. Anna Calori et al. (Berlin: De Gruyter, 2019). 
ready been connected by newly established modes of intercontinental exchange. These included personal migrations, new institutions, and official initiatives. Tanzanian trade unionists (such as Salvatory Kaindoah), students, and Swahili language teachers ventured to the GDR, while East German teachers, skilled workers, and technical experts were dispatched to build socialism in Tanzania. Beneath the official rhetoric of cooperation, however, ideas of internationalism and the best path to socialism often differed. Tanzania became, in the East German classification, not a "socialist country" but a country of "socialist orientation" that was still at a remove from "scientific socialism." ${ }^{\prime}$ Indeed, Tanzanian president Julius Nyerere, one of the main architects of the Arusha Declaration, always kept Marxism-Leninism at arm's length and publicly chastised as "failures" the "so-called socialist countries" in which a small minority had seized power and privilege. ${ }^{7}$

There was thus never a universally shared or stable understanding of where the socialist world began and where it ended. At least nominally, governments in no less than 35 out of 53 countries on the African continent used the term "socialist" to characterize their politics and policies between the late 1950s and the late 1980s. ${ }^{8}$ Many African socialisms in the 1960s and 1970s, though by no means all, shared characteristics. Examples of these traits were nationalization of key economic sectors for raw material exports, state-controlled marketing boards for agricultural produce, and universal and free education and healthcare. Ghana, Guinea, Tanzania, and Zambia are good examples of countries which followed this package of policies. Ethiopia, Tanzania, Mozambique, and Burkina Faso were the countries which attempted the most wide-ranging transformations of the all-important rural sector in the 1970s and 1980s. Many of the socialisms were also marked by "a doubling of the state into party and normal state administration, the concentration of strategic decision-making at the party

\footnotetext{
6 Eric Burton, “Tansanias 'Afrikanischer Sozialismus' und die Entwicklungspolitik der beiden deutschen Staaten: Akteure, Beziehungen und Handlungsspielräume, 1961-1990” (PhD diss., University of Vienna, 2017), 134-135.

7 Julius Nyerere, “Capitalism or Socialism: The Rational Choice,” New Blackfriars 55 (1974): 447. 8 Anne M. Pitcher and Kelly M. Askew, "African Socialisms and Postsocialisms," Africa 76 (2006): 1. See also Eric Burton, "Socialisms in Development: Revolution, Divergence and Crisis, 1917-1991,” Journal für Entwicklungspolitik 33 (2017): 5; Priya Lal, African Socialism in Postcolonial Tanzania: Between the Village and the World (Cambridge: Cambridge University Press, 2015); Mark Nash, ed., Red Africa: Affective Communities and the Cold War (London: Black Dog Publishing, 2016); Barry Munslow, ed., Africa: Problems in the Transition to Socialism (London: Zed, 1986); Edmond J. Keller and Donald S. Rothchild, ed., Afro-Marxist Regimes: Ideology and Public Policy (Boulder: Lynne Rienner, 1987).
} 
leaderships, highly centralized decision-making processes and a subordination of 'mass organizations' to the party line."

In view of the variety of socialisms in Africa, which often blended with "Third World" anti-imperialism and diverse forms of African nationalism, African socialist relationships with Soviet and East German Marxism-Leninism were complex. They were marked by both cooperation and tension, particularly as the anti-imperialist strand grew and diversified further. ${ }^{10}$ The bipolar Cold War paradigm was and is unable to explain these alliances and frictions. ${ }^{11}$ Similarly, the historiography of globalization has also ignored or marginalized these connections until very recently. As James Mark, Bogdan Iacob, Tobias Rupprecht, and Ljubica Spaskovska point out, "[t]he idea of Western capitalism as the sole engine for modernity has left us with a distorted view of socialist states as inward-looking, isolated, and cut off from global trends until the transition to capitalism in the 1990s." ${ }^{\prime 2}$ In the globalization discourse of triumphant liberalism which emerged in the early 1990s, and decisively shaped global history as an academic discipline, ${ }^{13}$ both Africa and Eastern Europe were neglected world regions. Too many analyses considered globalization to be a Western-led phenomenon in which neither the communist world nor African states - of varying ideo-

9 Joachim Becker, "Anatomie der Sozialismen: Wirtschaft, Staat und Gesellschaft," in Sozialismen: Entwicklungsmodelle von Lenin bis Nyerere, ed. Joachim Becker and Rudy Weissenbacher (Wien: Promedia, 2009), 40. Our translation.

10 William H. Friedland and Carl G. Rosberg, ed., African Socialism (Stanford: Stanford University Press, 1964); Allison Drew, "Communism in Africa," in The Oxford Handbook of the History of Communism, ed. S. A. Smith (Oxford, New York: Oxford University Press, 2014). Jodie Yuzhou Sun explores the influences of the Cold War, the political culture of individual African states (Kenya and Zambia), and their bilateral relations with communist countries, above all China, in Jodie Yuzhou Sun, "Historicizing African Socialisms: Kenyan African Socialism, Zambian Humanism, and Communist China's Entanglements," International Journal of African Historical Studies 52 (2019).

11 Daniel Speich, “The Kenyan Style of 'African Socialism': Developmental Knowledge Claims and the Explanatory Limits of the Cold War," Diplomatic History 33 (2009); Tony Smith, "New Bottles for New Wine: A Pericentric Framework for the Study of the Cold War," Diplomatic History 24 (2000).

12 James Mark et al., 1989: A Global History of Eastern Europe (Cambridge: Cambridge University Press, 2019), 7.

13 Sebastian Conrad, What Is Global History? (Princeton: Princeton University Press, 2016), 1-2. Sebastian Conrad maintains that "one of the crucial tasks of global history is to offer a critical commentary on the ongoing globalization process." Conrad, What Is Global History?, 212. 
logical colors - were thought to be active participants until the late 1980s. ${ }^{14}$ There are, however, good reasons to say that they were.

\section{Encounters, Moorings and (Dis)Entanglements}

The title of this volume refers to how encounters between people from various African states and East Germany were navigated and negotiated by a multitude of actors, who were pursuing a wide variety of interests. As mentioned above, the meanings of socialism and the substance of socialist relations were unstable and constantly subject to negotiation. Furthermore, in many everyday encounters, socialist goals were relegated to the background, overtaken by pragmatic imperatives. On other occasions, non-socialist ideologies such as nationalism or pan-Africanism took precedence. Inevitably, such a diversity of encounters had diverse outcomes. Above all, there were encounters which led to the establishment of new institutions and the migrations which resulted from those institutions. In many instances, flows and channels between South and East were newly established after the Second World War. In the absence of direct colonial links, there was often no historical precedent from which relations could be resumed. Johanna Bockman has argued that it was this relatively blank slate that made SouthEast interconnections "much more global than the old hierarchic metropole-colony relations, which the neo-liberal economic policies, often mistakenly labelled as globalization, reinforced." 15 The new ties represented the emergence of "alternative form[s] of global interconnectedness based on anti-imperialist geogra-

14 Anna Calori et al., "Alternative Globalization? Spaces and Economic Interactions between the 'Socialist Camp' and the 'Global South'," in Between East and South: Spaces of Interaction in the Globalizing Economy of the Cold War, ed. Anna Calori et al. (Berlin: De Gruyter, 2019), 7, our emphasis; James Mark and Tobias Rupprecht, "The Socialist World in Global History: From Absentee to Victim to Co-Producer," in The Practice of Global History: European Perspectives, ed. Matthias Middell (London: Bloomsbury, 2018); on the repercussions of colonialism and Africa’s marginalization in history writing see Táiwò Olúfẹmi, "What Is 'African Studies’? African Scholars, Africanists, and the Production of Knowledge," in Reclaiming the Human Sciences and Humanities Through African Perspectives, ed. Helen Lauer and Kofi Anyidoho (Accra: Sub-Saharan Press, 2012); David Simo, "Writing World History in Africa: Opportunities, Constraints and Challenges," in Global History, Globally: Research and Practice Around the World, ed. Sven Beckert and Dominic Sachsenmaier (London: Bloomsbury, 2018).

15 Johanna Bockman, "Socialist Globalization against Capitalist Neocolonialism: The Economic Ideas behind the New International Economic Order," Humanity: An International Journal of Human Rights, Humanitarianism and Development (2015): 125-127; the quote is also used in Calori et al., “Alternative Globalization,” 9. 
phies." ${ }^{16}$ Parastatal foreign trade companies engaged in barter trade as both sides often lacked the hard currency needed for exchange in a global financial system which was controlled by the United States and the international financial institutions. ${ }^{17}$ Transnational networks of youth organizations, trade unions, and political parties had partners in Europe, Africa, the Caribbean, South America, and across Asia. This wide participation formed axes of socialist mobilities, initially envisioned to be independent of the imperial fault lines which characterized the liberal globalization which had risen from the ashes of the colonial empires. $^{18}$

Though the contributions in this volume show a multitude of entanglements, they also demonstrate the ephemeral nature of many of the relationships, several of which were marked by tensions that allowed for rapid disentanglements. The most important rupture was, of course, the end of the GDR in 1990, when many institutionalized connections were abruptly discontinued. Even in earlier decades, however, many exchanges ended promptly and can therefore be aptly described as "temporary friendships" which passed from high hopes and enthusiasm to mutual disillusionment. ${ }^{19}$ Pertinent examples for such a course of events include relations between Zanzibar and the GDR in the 1960s (Burgess, this volume), or the coffee trade with Ethiopia in the late 1970s, both discussed below. The temporary and fragmented character of many relations is captured in the metaphor of "moorings." The word describes the anchoring of a ship or the fixing of a moving object more generally. Some authors in mobility studies have emphasized the dialectical relationship between mobility and moorings; they argue that "mobilities cannot be described without attention to the necessary spatial, infrastructural and institutional moorings that configure and enable mobilities." ${ }^{20}$ Mobility is only possible through the existence of multiple fixed institutions or infrastructure, and mooring is only possible if there is something

16 Mark et al., 1989: A Global History of Eastern Europe, 9.

17 Vijay Prashad, The Poorer Nations: A Possible History of the Global South (London: Verso, 2014), 25.

18 See e.g. Ismay Milford, "More Than a Cold War Scholarship: East-Central African Anticolonial Activists, the International Union of Socialist Youth, and the Evasion of the Colonial State (1955-65)," Stichproben: Vienna Journal of African Studies 34 (2018); Tal Zalmanovich, "From Apartheid South Africa to Socialist Budapest and Back: Communism, Race, and Cold War Journeys," Stichproben: Vienna Journal of African Studies 34 (2018).

19 The term temporary friendships is borrowed from the film program "Temporary Friendships - Contract Labor and Internationalism in the GDR”, bi'bak, Berlin, October 24 - November 22, 2019, bi-bak.de/en/bi-bakino/freundschaft-auf-zeit.

20 Kevin Hannam, Mimi Sheller, and John Urry, "Editorial: Mobilities, Immobilities and Moorings,” Mobilities 1 (2006): 3, accessed December 5, 2019, doi:10.1080/17450100500489189. 
immobile to moor onto. ${ }^{21}$ In this volume, however, we employ the mooring metaphor in a temporal rather than a physical sense. Given that few of the African and East German actors involved in the exchanges stayed abroad for the long-term, most individual experiences were moorings rather than rootings (in the sense of putting down roots). Akin to sailors who reminisce about their journeys once they get home, East German travelers to African countries and African sojourners in the GDR think back to their moorings which allowed them to learn and work abroad for a few weeks, months or even years (Burgess; Machava; Osei, annotated by Harisch; Bodie; Sprute; Bahr; Buanaissa and Piepiorka, all this volume). In the light of this, we frame the encounters between Africans and East Germans as moorings which entangled - and, with time, unmoored and disentangled - two continents through patchy personal, institutional, and linguistic webs. The contributions to this volume show how people and institutions produced new forms of transregional interconnectedness, but also how hierarchies and structures limited the possible impact of these encounters.

Historically grounded limitations impacted relations between Africa and the “East” more generally. In the economic realm, political independence did not much disrupt African dependence on vital trade links between former colonies and their erstwhile colonial powers, as governments of newly-independent states usually kept these dense economic networks with the Western capitalist states intact. ${ }^{22}$ Moreover, while the Soviet Union and the socialist states of Eastern Europe helped to diversify the sources for much sought-after foreign assistance, most investment in African economies still came from Western governments or Western multinational corporations. This was also the case in Africa's socialist states. ${ }^{23}$ Mining contracts for Guinean bauxite or Zambian copper, or oil exploration in Congo-Brazzaville or Angola, were, for the most part, continued with Western capitalist firms. In the cultural realm, most African countries adopted the colonial language as national language and retained many aspects of the colonial education system. At the same time French, English or Portuguese were rarely taught in Eastern Europe. ${ }^{24}$ These limitations, the lack of financial clout with which the Eastern Bloc could penetrate the economies of postcolonial African countries, and the inability to converse in a shared language, were only some

21 Ibid.

22 Iba der Thiam, James Mulira, and Christophe Wondji, “Africa and the Socialist Countries," in Unesco General History of Africa VIII: Africa since 1935, ed. Ali A. Mazrui and C. Wondji (California: University of California Press, 1993), 808-809.

23 Ralph A. Austen, African Economic History: Internal Development and External Dependency (London: James Curry, 1987), chap. 9.

24 Thiam, Mulira and Wondji, "Africa and the Socialist Countries," 809. 
of the factors which hampered the establishment of more durable ties between socialist Eastern European countries and Africa. Another factor in relations was that many East German actors also carried, without much self-reflection about it, the cultural legacy of an attitude of superiority vis-à-vis Africa. This mentality dated back at least to the nineteenth century and the period of Imperial Germany's colonial possessions. It was, furthermore, compounded by the even more explicitly racist legacy of Nazi Germany. The GDR officially distanced itself both from its colonial and Nazi past, but both pasts remained largely undiscussed and unexamined with regard to individual family histories and world views. ${ }^{25}$ East Germany was the only country in the communist Eastern Bloc with a history of colonial rule in Africa, though it was certainly not the only country whose citizens often bore an (at best) condescending attitude towards Africans. While the SED government successfully managed to distance itself from Imperial Germany in the eyes of many of its African interlocutors, the legacies of racist attitudes permeated cross-continental everyday encounters.

Although they were often of limited duration and constrained by several factors, the South-East exchanges and moorings nevertheless left their marks. During their time in the GDR, African students tried to set up associations which called for East German media to stop portraying modern Africa in the exoticizing manner which prevailed at that time (Alvarado; Angermann, this volume). Mozambican contract workers not only exchanged their labor power for education and pay in the GDR, but also brought home East German goods that changed the war economy in Maputo in ways that lasted for years (Machava, this volume). The East German and Mozambican governments established an agreement for Mozambican workers to migrate to East Germany to work and receive training, which lastingly entangled both countries economically, politically, and socially (Rantzsch, this volume). In the contribution by Schenck and Alberto we read about the personal consequences of the institutional disentanglements and the dissolution of the contract after the GDR ceased to exist. There was, therefore, a complex assemblage of multi-directional processes within these SouthEast relationships, which led to diverse and at times contradictory outcomes.

25 Peggy Piesche, "Making African Diasporic Pasts Possible: A Retrospective View of the GDR and Its Black (Step-)Children," in Remapping Black Germany: New Perspectives on Afro-German History, Politics, and Culture, ed. Sara. Lennox (Massachusetts: University of Massachusetts Press, 2016). 


\section{Africa and East Germany: Alternative Forms of Transcontinental Interconnectedness in Global History}

The perspectives of actors from both the "South" and the "East" have been marginalized in global history. ${ }^{26}$ This volume investigates South-East relations through a focus on global socialism and diverse transregional entanglements between actors from the African continent and the GDR. ${ }^{27}$ It places African history into global history by highlighting connections between Africans and East Germans and their institutions during the Cold War. The volume focuses predominantly on non-elite figures and the possibilities and constraints of their agency. In this way, the scholars contributing to this collection highlight Africans' and Eastern Europeans' visions of African and global futures, which were often shaped by socialism in its numerous imaginations and manifestations. The book thus contributes to the discussions about the nature of global socialism(s), and how it shaped and was shaped by African actors and institutions. The contributions foreground "alternative form[s] of global interconnectedness" ${ }^{28}$ by showing the many ways in which actors from different vantage points in the socialist world thought about socialism, both locally and globally, and how they navigated the new hierarchies of a global socialism in the making.

Following an interdisciplinary and initially multilingual ${ }^{29}$ approach, this volume offers a platform for scholars from three continents (Africa, Europe, and

26 Arno Sonderegger, Ingeborg Grau, and Birgit Englert, "Einleitung: Afrika im 20. Jahrhundert," in Afrika im 20. Jahrhundert: Geschichte und Gesellschaft, ed. Arno Sonderegger, Ingeborg Grau, and Birgit Englert (Wien: Promedia, 2011), 9-11; Calori et al., "Alternative Globalization?," 7-9.

27 For a similar approach regarding entanglements with Vietnam, see Christina Schwenkel, "Socialist Mobilities: Crossing New Terrains in Vietnamese Migration Histories," Central and Eastern European Migration Review 4 (2015); see also Alena K. Alamgir, "Labor and Labor Migration in State Socialism," Labor History 59 (2018).

28 Mark et al., 1989, 9.

29 The original contributions were based on work in English, German, and Portuguese. While scholars like Jeremy Adelman and Drayton and Motadel have rightly lamented that English is becoming "globish" and hegemonial in global history, the current publishing rules did not allow the editors of this volume to go ahead with their original plan to publish this book as a trilingual edited volume in English, German, and Portuguese. See Jeremy Adelman, "What is global history now?," Aeon, accessed October 9, 2019, https://aeon.co/essays/is-global-historystill-possible-or-has-it-had-its-moment; Richard Drayton and David Motadel, "Discussion: The Futures of Global History,” Journal of Global History 13 (2018): 15. 
North America) and various disciplines (ranging from history to German studies to education studies) to present their research. They employ a range of methodological approaches to the study of South-East relations, including oral history, the consultation of both Eastern European and African archives, the study of literature and of international academic networks. Throughout, they strive to maintain a balance between African and East German actors' perspectives. In this vein, the open access format of this volume contributes to the international accessibility of knowledge generated across national boundaries, and we invite further transregional cooperation - particularly with scholars from Africa and with researchers using African sources - in investigating the pasts and legacies of these interconnections.

With a special focus on negotiations, entanglements, and African influences on East Germany (and vice versa), the volume sheds light on personal and institutional agency, cultural cross-fertilization, migration, development, and solidarity in everyday encounters. It explores the repercussions and legacies of these South-East encounters and examines in which ways the enmeshed power structures and inequalities remain relevant up to the present day. By demonstrating the diversity of socialisms and connections to the East on the African continent, this edited volume challenges, possibly complicates, but ultimately deepens our understanding of how Africa fitted into what was, for a time, a global socialist world.

\section{Writing South-East Relations into Global History}

Global history has been on the rise for the past two decades, but, as set out above, all too often the kind of global history produced has been synonymous with a history of Western-led globalization. ${ }^{30}$ However, recent studies have suggested that the study of alternative forms of globalization, spurred by socialism and the process of decolonization, enriches and complicates our understanding of globalization. Oscar Sanchez-Sibony, for instance, has examined the political economy of what he calls "red globalization," highlighting Soviet responses to trade initiatives from the Global South in the 1950s and 1960s. ${ }^{31}$ Johanna Bockman has engaged with what she refers to as "socialist globalization," seeing

30 Frederick Cooper, "What Is the Concept of Globalization Good for? An African Historian's Perspective," African Affairs 100 (2001); Lynn Hunt, Writing History in the Global Era (New York: Norton, 2014).

31 Oscar Sanchez-Sibony, Red Globalization: The Political Economy of the Soviet Cold War from Stalin to Khrushchev (Cambridge: Cambridge University Press, 2014). 
it as an alternative political project to "capitalist neocolonialism," in her work about the role of the United Nations Conference on Trade and Development (UNCTAD) in negotiating the parameters of the mooted New International Economic Order. ${ }^{32}$ In the literature on globalization, the portrayal of state socialist Europe thus underwent a significant transformation: previously seen as an absentee from or a victim of (Western) capitalist globalization, it is now recognized as a co-producer of globalization, or as an instigator of alternative globalization(s). ${ }^{33}$ Recent scholarship, produced mainly by historians of East Central Europe and the Soviet Union, has discussed relations between the "Second World" and the "Third World," or the Cold War East and the Global South, under terms such as "internationalism," "red globalization," and "Warsaw Pact Intervention in the Third World." 34

The contributions to this volume demonstrate that alternative forms and ideas of globalization were about much more than just economic orders and rhetoric of political elites. We examine cultural, social, political, and economic encounters in a global socialist world. In doing so, we build on important works from other scholars who have investigated relations between Africa and the GDR. A first wave of literature arrived in the early 1990s, with many groundbreaking studies based on new archival records as well as valuable first-hand accounts of former diplomats, journalists, students, and experts. These studies generally framed relations between the GDR and Africa in mostly bilateral terms, usually highlighted East German perspectives, and frequently took a

32 Bockman, "Socialist Globalization," 6.

33 Mark and Rupprecht, "The Socialist World in Global History."

34 Odd A. Westad, The Global Cold War: Third World Interventions and the Making of Our Times (Cambridge: Cambridge University Press, 2005); Maxim Matusevich, ed., Africa in Russia, Russia in Africa: Three Centuries of Encounters (Trenton, NJ: Africa World Press, 2007); David C. Engerman, "The Second World's Third World," Kritika: Explorations in Russian and Eurasian History 12 (2011); Sanchez-Sibony, Red Globalization; Tobias Rupprecht, Soviet Internationalism after Stalin: Interaction and Exchange between the USSR and Latin America during the Cold War (Cambridge: Cambridge University Press, 2015); Matthias Middell, "Weltgeschichte DDR: Die DDR in globalgeschichtlicher Perspektive," in Die DDR als Chance: Neue Perspektiven auf ein altes Thema, ed. Ulrich Mählert (Berlin: Metropol Verlag, 2016); Philip E. Muehlenbeck and Natalia Telepneva, ed., Warsaw Pact Intervention in the Third World: Aid and Influence in the Cold War (London: I.B. Tauris, 2018); Matthias Middell, "Auf dem Weg zu einer transregionalen Geschichte des Kommunismus," in Kommunismus jenseits des Eurozentrismus: (= Jahrbuch für Historische Kommunismusforschung), ed. Matthias Middell, (Berlin: Metropol, 2019); James Mark, Artemy M. Kalinovsky, and Steffi Marung, ed., Alternative Globalizations: Eastern Europe and the Postcolonial World (Bloomington: Indiana University Press, 2020). 
comparative view with West German policies and practices. ${ }^{35}$ A second wave of historiographical scholarship has investigated relations between Africa (and other regions) and the GDR, focusing on power asymmetries, including reflections on the complex workings of race and the contested and ambivalent meanings of terms such as "solidarity" and "mutual benefit." 36 Works from either wave, however, have not explicitly discussed how relations between Africa and East Germany enrich our understanding of global history and processes of globalization.

Far from subscribing to a point of view that sees globalization as a singular homogenizing process engulfing the world, or as a Western project spreading by diffusion, we conceive of globalizations in the plural. This entails visualizing globalization "as a set of multidirectional processes stemming from different world regions." 37 This includes the African continent, as well as socialist Eastern Europe (in a geopolitical rather than geographical sense). ${ }^{38}$ As the contributions

35 Ulrich van der Heyden, Ilona Schleicher, and Hans-Georg Schleicher, ed., Die DDR und Afrika: Zwischen Klassenkampf und neuem Denken (Münster: Lit, 1993); Ulrich van der Heyden, Ilona Schleicher, and Hans-Georg Schleicher, ed., Engagiert für Afrika: Die DDR und Afrika II (Münster: Lit, 1994); Jude Howell, “The End of an Era: The Rise and Fall of G.D.R. Aid,” in Journal of Modern African Studies 32 (1994); Brigitte H. Schulz, Development Policy in the Cold War Era: The Two Germanies and Sub-Saharan Africa, 1960-1985 (Münster: Lit, 1995); Ulf Engel and Hans-Georg Schleicher, Die beiden deutschen Staaten in Afrika: Zwischen Konkurrenz und Koexistenz, 1949-1990 (Hamburg: Institut für Afrika-Kunde, 1998); Hans-Joachim Döring, Es geht um unsere Existenz: Die Politik der DDR gegenüber der Dritten Welt am Beispiel von Mosambik und Äthiopien (Berlin: Ch. Links, 1999); Ulrich van der Heyden and Franziska Benger, ed., Kalter Krieg in Ostafrika: Die Beziehungen der DDR zu Sansibar und Tansania (Münster: Lit, 2009). One of the few studies based on African archival materials is Haile G. Dagne, Das entwicklungspolitische Engagement der DDR in Äthiopien: Eine Studie auf der Basis äthiopischer Quellen (Münster: Lit, 2004).

36 Toni Weis, “The Politics Machine: On the Concept of 'Solidarity' in East German Support for SWAPO,” Journal of Southern African Studies 37 (2011); Hubertus Büschel, Hilfe zur Selbsthilfe: Deutsche Entwicklungsarbeit in Afrika 1960-1975 (Frankfurt am Main: Campus, 2014); YoungSun Hong, Cold War Germany, the Third World, and the Global Humanitarian Regime (New York: Cambridge University Press, 2015); Quinn Slobodian, ed., Comrades of Color: East Germany in the Cold War World (New York: Berghahn Books, 2015).

37 Calori et al., "Alternative Globalization," 9.

38 For a thoughtful review and rethinking of the concept of the "bloc" see also Steffi Marung, Uwe Müller and Stefan Troebst, "Monolith or Experiment? The Bloc as a Spatial Format," in Spatial Formats under the Global Condition, ed. Matthias Middell and Steffi Marung (Berlin: De Gruyter, 2019). See also the argument by Marcia C. Schenck about the "Black East" constituting a geographic entity with blurry borders as much as a political and social entity in Marcia C. Schenck, "Constructing and Deconstructing the "Black East" - a Helpful Research Agenda: Research Note,” Stichproben Vienna Journal of African Studies 34 (2018): 136. 
to this volume and other works have shown, many instances of South-East entanglement shared certain characteristics (e. g. a focus on education, see Alvarado, this volume). At the same time, actors from countries such as Yugoslavia or China pursued globalizing strategies which differed from, or openly challenged, Soviet leadership of the anti-imperialist camp. These divisions sometimes came into play in encounters on the ground. For instance, in Zanzibar, the GDR and the People's Republic of China competed for the role of the most influential patron (Burgess, this volume). Socialist globalization can therefore be conceived of as a series of political projects in which actors chose to engage in response to global challenges and competitions. In the terminology of world-systems theory, they were often seeking both to catch up with and to challenge the capitalist core from a peripheral or semi-peripheral position. ${ }^{39}$ Elites in many African countries were able to decide how much to invest in relations with the West, and where to engage in relations with different actors from the East to increase their bargaining power vis-à-vis the other partner (see, for instance, the example of Egypt in Depta and Hartmetz's contribution, this volume). On other occasions, such as the French retaliation after Guinea's 1958 vote for immediate independence instead of membership in the French Community, or the exodus of mostly white professional staff from Angola and Mozambique in the mid-1970s, Western hostility made stronger links to networks of socialist globalization a matter of economic survival.

While much has been written about elite actors in the Cold War, this volume demonstrates that relations were, in fact, often fostered by non-elite actors and by state projects which brought Africans together with East German partners along socialist axis to shape an alternative vision of global interconnectedness. It follows that the trend seen in the last 70-or-so years, of increasing global interconnectedness, does not automatically go hand in hand with the liberal globalization model with which it is usually associated. ${ }^{40}$ As the contributions in this volume demonstrate, studying alternative forms of global entanglements does not have to come at the cost of national histories or "small spaces" and micro histories, and most certainly do not depoliticize these stories, as is sometimes claimed. ${ }^{41}$ Quite to the contrary, analysis of concrete complaints about racism (Angermann, this volume), individual photos (Bahr, this volume), or entries in brigade diaries (Sprute, this volume) reveal both the reach and limits of official policies and of the socialist rhetoric of friendship and solidarity. Studying the

39 Mark and Rupprecht, "The Socialist World in Global History."

40 Middell, "Weltgeschichte," 153.

41 Drayton and Motadel, "Discussion," 1-3. 
limits and fictions of entanglements tells us as much about their meaning as does studying their existence and achievements.

\section{Writing Africa into Global History}

The concept of globalization, when it is used to refer to a universal, Western-led process of integration, easily glosses over the complexities and diversity of actual connections and actors. ${ }^{42}$ This does by no means imply a neglect of global dimensions. As Frederick Cooper emphasized, the "and" in DuBois' title The World and Africa implies two directions of causality and serves as a reminder that "African history should be studied in all its complexity, but not as if 'Africa' existed independently of the rest of the world." 43 Recent approaches - including this series, Africa in Global History - address the global connections which shaped African histories and which aim to fully incorporate the African continent into the "global turn". They usually embrace DuBois' and Cooper's imperative and frame Africa firmly within the study of globalizing processes. Some authors speak of "Africa in the globalizing world," others of "Africa within the global." 44 These formulations also signal that there is no consensus as to whether, and in what ways, Africa may also be seen as a producer of globalization. This is a discussion which will keep the field engaged for a while to come and to which this volume provides empirical research perspectives. ${ }^{45}$ It offers avenues towards a global history of socialism by merging two strands of global history: Africa in global history and South-East entanglements. In the process of editing this volume we have come to appreciate the complexities of such an endeavor. It was not easy to achieve a balanced viewpoint, and in the final result more contributors and primary sources speak from the East German than from the African point of view. To a certain extent this was to be expected, given the inherent GDR-centric nature of a volume using the GDR as a unifying feature studying entanglements with socialisms across Africa. However, this volume would be

42 Cooper, "What Is the Concept of Globalization Good for?".

43 Cooper, Africa in the World, 9.

44 Ulf Engel et al., "Africa in the Globalizing World - a Research Agenda," Comparativ 27 (2017); Pedro Machado, "Repositioning Africa within the Global," Africa Today 63 (2016). See also the other insightful contributions to the section "Symposium: African Studies and the Challenge of the 'Global' in the 21st Century" in this issue of Africa Today.

45 James Ferguson, Global Shadows: Africa in the Neoliberal World Order (London: Duke University Press, 2006), especially chap. 1. 
equally hard to be put together in a balanced way if it was, for example, examining Mozambique's entanglements with the Eastern Bloc.

A worthwhile future endeavor, which takes up the Afro-Asian Networks Research Collective's call to examine South-South relations, would be to examine the socialist encounters in networks created and maintained between African actors beyond the trodden paths of diplomatic relations of nation-states. ${ }^{46}$ Yet, this volume succeeds in showing how "African actors navigated, ignored, and subverted the power dynamics of the Cold War"47 and that many contributions actually follow a "research agenda that privileges transnational networks of affinity"48 - and of friction - across Africa and Europe.

We should not close our eyes to the fact that there is an inequality of research output on the global socialist world that sees many more actors from the Global North engage in this research topic than scholars from the Global South. To our knowledge, current contributions in the field of South-East entanglements rarely include scholars from based in Africa who investigate these relations by drawing on archival materials and oral histories from their region of origin. ${ }^{49}$ The multiple reasons for this global inequality of knowledge production and pitfalls of transcontinental partnerships have been discussed elsewhere, ${ }^{50}$ but it is worth noting explicitly the effect of the different funding landscapes and intellectual freedoms, especially in the context of writing global history. For this volume we found it difficult to get contributors from African universities, reflecting that the research agendas of global history and South-East relations are currently not well established at most African institutions of higher

46 Afro-Asian Networks Research Collective, "Manifesto: Networks of Decolonization in Asia and Africa," Radical History Review 131 (2018).

47 Afro-Asian Networks Research Collective, "Manifesto," 178.

48 Afro-Asian Networks Research Collective, "Manifesto," 177.

49 An account on Ghana's relations with the Soviet Union based on Ghanaian sources by a USbased scholar is Nana Osei-Opare, "Uneasy Comrades: Postcolonial Statecraft, Race, and Citizenship, Ghana-Soviet Relations, 1957-1966," Journal of West African History 5 (2019). We are, however, not aware of works which are using archival documents of the MPLA or FRELIMO to examine the relations of Angola or Mozambique with socialist states as of now. Archival access seems to be an impediment to engaging with this research topic from African perspectives. For a recent discussion of Mozambican archives see Ingrid Miethe et al., Globalization of an Educational Idea: Workers' Faculties in Eastern Germany, Vietnam, Cuba and Mozambique (Berlin: De Gruyter, 2019), 34-35.

50 Amina Mama, "Is it Ethical to Study Africa? Preliminary Thoughts on Scholarship and Freedom, “African Studies Review 50 (2007); Loren B. Landau, “Communities of Knowledge or Tyrannies of Partnership: Reflections on North-South Research Networks and the Dual Imperative," Journal of Refugee Studies 25 (2012). 
education. ${ }^{51}$ Seen from the African research landscape today, relations with the GDR are a rather marginal topic..$^{52}$ This suggests that the impact of the GDR was either not that profound or is a silenced topic in current political discourse, or most likely a bit of both.

Considering this, why should a volume on Africa in global history bring the GDR into the picture? There are many good reasons. Firstly, Africa - both south and north of the Sahara - serves as a crucial vantage point for investigating South-East relations and the alternative futures that these ties promised. There is a growing body of Africanist scholarship with a global history perspective, yet relations with the geopolitical Cold War "East" are often only mentioned in passing. ${ }^{53}$ Similarly, connections with Africa have been absent in most of the historiography on East Germany. As Sebastian Pampuch points out, the "idea of a post-colonial world that breaks with the inequalities of capitalism through socialist modernization is one of these repressed histories." Such histories can also resituate the GDR in a transregional perspective. ${ }^{54}$ This neglect does justice neither to African countries nor to the heterogenous socialist states. The unfolding decolonization process on the African continent in the 1950s and

51 Generally, one has to acknowledge the research constraints at many public African universities today that are an echo of the IMF and World Bank induced cuts on tertiary education from the late 1970s onward after the "golden age" of knowledge production at a number of African universities in the 1960s and early 1970s. See Esperanza Brizuela-Garcia, "African Historiography and the Crisis of Institutions," in The Study of Africa Volume 1: Disciplinary and Interdisciplinary Encounters, ed. Paul Tiyambe Zeleza (Dakar: Codesria, 2006); Mahmood Mamdani, Scholars in the Marketplace: The Dilemmas of Neo-Liberal Reform at Makerere University, 1989-2005 (Dakar: CODESRIA Council for the Development of Social Science Research in Africa, 2007). 52 Nonetheless, two Ethiopian exceptions should be mentioned: Dagne, Das entwicklungspolitische Engagement and Gebru Tareke, The Ethiopian Revolution: War in the Horn of Africa (New Haven \& London: Yale University Press, 2009). Like the majority of German historical studies on relations between Socialist Ethiopia and the GDR, however, they focus mostly on military and economic aspects and less on everyday encounters. See Hans-Joachim Döring, "Es geht um unsere Existenz": Die Politik der DDR gegenüber der Dritten Welt am Beispiel von Mosambik und Äthiopien (Berlin: Ch. Links, 1999) and Klaus Storkmann, Geheime Solidarität. Militärbeziehungen und Militärhilfen der DDR in die "Dritte Welt” (Berlin: Ch. Links, 2012).

53 Important exceptions include Osei-Opare, "Uneasy Comrades”; Sun, "Historicizing African Socialisms"; Jocelyn Alexander and JoAnn McGregor, "African Soldiers in the USSR: Oral Histories of ZAPU Intelligence Cadres' Soviet Training, 1964-1979," Journal of Southern African Studies 43 (2017); Jamie Monson, Africa's Freedom Railway: How a Chinese Development Project Changed Lives and Livelihoods in Tanzania (Bloomington: Indiana University Press, 2009).

54 Sebastian Pampuch, “Afrikanische Freedom Fighter im Exil der DDR: Dekoloniale Wissensbestände einer 'unerwünschten Geschichte'," in Wissen in Bewegung: Migration und Globale Verflechtungen in der Zeitgeschichte seit 1945, ed. Stephanie Zloch, Lars Müller, and Simone Lässig (Berlin: De Gruyter, 2018), 325. Our translation. 
1960s - and the breakdown of the Portuguese Empire in the mid-1970s - breathed new life into the belief in socialist world revolution as well as postcolonial emancipation. "National democracies" in Africa were to serve as trading partners as well as crucial allies against Western capitalist neocolonialism. African actors were interested in the Eastern Bloc (whose name misleadingly suggests homogeneity and uniformity of interests ${ }^{55}$ ) as new trade partners, partners for professional and cadre training, and supporters of liberation struggles - most actively against the white minority regimes in southern Africa. These ties sometimes offered radical alternatives, but sometimes only additional elements to Western discourses on development. Colonial legacies continued to shape the opportunities and constraints of postcolonial African governments to varying degrees. ${ }^{56}$

These efforts to overcome peripherality are part of a longer and broader history that also includes connections across the Black Atlantic. African interests and roles in co-producing alternative forms of global interconnectedness have been bound up with the question of how to overcome the peripherality imposed by colonialism, and the asymmetries in the global order that came with it. Already in the first half of the twentieth century, African, African-American, and West Indian intellectuals, such as W. E. B. DuBois, George Padmore, C. L. R. James, Tiemoko Garan Kouyaté, and Kwame Nkrumah set up revolutionary socialist publication organs ${ }^{57}$ and established wide anticolonial networks. These networks, at times, included the Soviet Union ${ }^{58}$ and Western communist parties and creatively adapted Marxist and Leninist thought for use in their analyses of African affairs and their calls for decolonization. ${ }^{59}$ In the aftermath of World War

55 Marung, Müller, and Troebst, "Monolith or Experiment?".

56 Frederick Cooper, "Possibility and Constraint: African Independence in Historical Perspective,” The Journal of African History 49 (2008).

57 Matthew Quest, “George Padmore’s and C. L. R. James’s International African Opinion,” in George Padmore: Pan African Revolutionary, ed. Fitzroy Baptiste and Rupert Lewis (Kingston: Ian Randle, 2009).

58 It is important to note, however, that the relationship of these mostly undogmatic Black Marxist thinkers and activists with Stalin's Soviet Union was an uneasy one; C. L. R. James, for example, favored Trotzky over Stalin and George Padmore had already broke with the Soviet Union during the 1930s. See Hakim Adi, Pan-Africanism: A History (London: Bloomsbury, 2018); Arno Sonderegger, "Der Panafrikanismus im 20. Jahrhundert," in Afrika im 20. Jahrhundert: Geschichte und Gesellschaft, ed. Arno Sonderegger, Ingeborg Grau and Birgit Englert (Wien: Promedia, 2011).

59 Leslie James, George Padmore and Decolonization from Below: Pan-Africanism, the Cold War, and the End of Empire (Houndmills: Palgrave Macmillan, 2015); C. L. R. James, A History of Negro Revolt (Chicago: Research Associates School Times Publications, 2004 [1938]); Kwame Nkrumah, Towards Colonial Freedom: Africa in the Struggle against World Imperialism (London: Panaf 
II, DuBois took a fresh look at the "old hierarchic metropole-colony relations" mentioned by Johanna Bockman. In The World and Africa: An Inquiry into the Part which Africa Has Played in World History, mentioned above, DuBois argued in 1946 that the devastating experience of the Second World War rendered it impossible for colonial business to go on as usual, providing an opening for Africans to redefine their place in the world.$^{60}$ For many aspiring African politicians after the Second World War, socialism promised an alluring break with the colonial and neocolonial order. Their experience of capitalist exploitation and institutionalized racism under European colonialism made socialism an attractive foundation on which to build their visions of modernity.

The second reason for bringing the GDR into African global history is that Afro-European encounters, under the banner of socialism, led to a dialectical process of globalizing on both sides of the equation. What Maxim Matusevich and Constantin Kastakioris have postulated for the 1960s Soviet Union ${ }^{61}$ was true for the GDR as well. The presence of, and interactions with Africans, alongside South Asians and Latin Americans, modernized and globalized East German society. A number of chapters in this volume demonstrate these adaptive processes in detail. Depta and Hartmetz's contribution examines the institutionalization of teaching and the use of German as a foreign language. Both Alvarado and Angermann show how African student unions tested the limits of regulations laid down by the SED while individual members of these unions criticized the portrayal of Africans in GDR media. Journalists like Ulrich Makosch, as George Bodie's contribution shows, brought the struggle of the Frente de Libertação

Books, 1979 [1945]); George Padmore, How Britain Rules Africa (New York: Negro Universities Press, 1969 [1936]). See also Arno Sonderegger, "How the Empire Wrote Back: Notes on the Struggle of George Padmore and Kwame Nkrumah,” in Kwame Nkrumah 1909-1972: A Controversial African Visionary, ed. Bea Lundt and Christoph Marx (Stuttgart: Franz Steiner Verlag, 2016). 60 W. E. B. Du Bois, The World and Africa: An Inquiry into the Part Which Africa Has Played in World History (New York: International Publishers, 1965 [1946]); see also Cooper, Africa in the World.

61 Maxim Matusevich, "Expanding the Boundaries of the Black Atlantic: Af, Africa in the World. Maxim Matusevich, "Expanding the Boundaries of the Black Atlantic: African Students as Soviet Moderns," Ab Imperio 2 (2012), doi:10.1353/imp.2012.0060. Constantin Kastakioris, "Transferts Est-Sud. Échanges Éducatifs et Formation de Cadres Africains en Union Soviétique Pendant les Années Soixante," Outre-mers 94 (2007); idem, “African Intellectuals and the Soviet Union: Internationalism, Pan-Africanism, and Négritude During the Years of Decolonization: 19541964," Cahiers du monde russe 47 (2006); idem, "Students from Portuguese Africa in the Soviet Union, 1960 - 74: Anti-Colonialism, Education, and the Socialist Alliance," Journal of Contemporary History (2020), accessed August 1, 2020, doi:10.1177/0022009419893739; idem, "The Lumumba University in Moscow: Higher Education for a Soviet-Third World Alliance, 1960 -91,” Journal of Global History 14 (2019). 
de Moçambique (FRELIMO) against Portuguese colonial troops into East German living rooms. Conversely, Paul Sprute shows how friendship brigades in Angola aimed to contribute to an Angolan socialist modernity by invoking the "Neuerer movement" (Neuererwesen), an approach which encouraged workers to propose ways to increase productivity. As Fernando Agostinho Machava shows in his chapter, East German televisions, fridges, and motorbikes, imported by former Mozambican contract workers, profoundly impacted the consumer landscape of neighborhoods in which they were received. Lastly, the possibility for East Germans to travel abroad marked another aspect of the globalizing effect of the GDR's entanglements with Africa. This is taken up in the contributions of Katrin Bahr, Alexandra Piepiorka and Eduardo F. Buanaissa, and Paul Sprute.

The third reason for the significance of the GDR to African global history is that the richness of available but frequently untapped sources lends itself to exploring the relations between Africa and the GDR in a global history perspective. In terms of archival material - often notoriously hard to come by for the post-independence period in many African countries - the GDR is a treasure trove. ${ }^{62}$ The outstanding range and accessibility of archival documents is due to the - for the historian fortuitous - fact that the GDR as a state ceased to exist. The German Federal Republic as successor state, together with activists from the former GDR, ensured the broad availability of archival records pertaining to the state and especially the secret police (Stasi). With regards to Africa, the archival records of the GDR constitute a transnational "shadow archive" which holds primary documents of crucial interest for scholars of African history. ${ }^{63}$ Several contributions in this volume draw on East German state and party archives as well as records of mass organizations (Depta/Hartmetz; Angermann; Rantzsch; Bodie; Sprute), university archives (Depta/Hartmetz), and the archives of the secret police and the ministry of foreign affairs (Rantzsch).

Of course, this is but a starting point. We believe that the GDR archives on which many of the contributions to this volume are based are useful for carving out the agency of African actors and introduce some African voices, particularly if read against the grain. It is nevertheless evident that research which makes further use of African sources is indispensable for a balanced approach. This includes archival documents on the African continent (Alvarado), oral history interviews (Machava), novels of African authors (Burgess), and African and

62 Steven Ellis, “Writing Histories of Contemporary Africa," Journal of African History 43 (2002). 63 Jean Allman, "Phantoms of the Archive: Kwame Nkrumah, a Nazi Pilot Named Hanna, and the Contingencies of Postcolonial History-Writing," The American Historical Review 118 (2013): 121; Kate Skinner, "West Africa's First Coup: Neo-Colonial and Pan-African Projects in Togo's 'Shadow Archives'," African Studies Review 6 (2019). 
diaspora print cultures. The chapters in this volume thus draw on official sources, but also semi-official collective diaries of volunteer "brigades" including poems and drawings (Brigadetagebücher, Sprute), photographs from personal collections (Bahr), and personal memories (Schenck with Alberto, Schenck with Raposo). With this variety of sources, the contributing authors approach relations between East Germany and Africa from a variety of perspectives.

The entanglements that the alternative global formations of socialist internationalism afforded may have been marginalized by the ruthless tide of mainstream politics and history, but they are still recalled by many as powerful symbols of aspiration to alternative modernities and futures. The contributions to this volume are divided into three sections. The first section, "Shaping Pioneering Institutions," focuses on the ways in which institutions were set up for and shaped by relations between Africa and the GDR. The second section, "Navigating the GDR: Moorings and (Dis)Entanglements," brings together examples of how temporary stays and engagements led to both long-term legacies as well as rapid disentanglements. The third section, "Sourcing Visions of Solidarity," comprises contributions which discuss sources giving unique insights into the perspectives of non-elite actors, including travel writing, the collective diaries of friendship brigades, private photographs, and oral history interviews. These sources open avenues to rethink the characteristics, relevance, and scope of South-East relations in the history of the twentieth century, as well as how Africa and East Germany fit into the global perspective. The regional focus of the contributions in this volume reflect the close ties that the GDR maintained to socialist countries in Africa, especially the profound relations with Mozambique, but also with Angola, Ghana, and Tanzania - though Ethiopia, another important case study, is unfortunately absent here. The following sketch of an entangled history, ${ }^{64}$ from the early 1950s to the late 1980s and beyond, gives an overview of socialist encounters and alternative forms of global interconnectedness.

64 Sebastian Conrad and Shalini Randeria, ed., Jenseits des Eurozentrismus: Postkoloniale Perspektiven in den Geschichts- und Kulturwissenschaften (Frankfurt: Campus Verlag, 2002); Michael Werner and Bénédicte Zimmermann, "Beyond Comparison: Histoire Croisée and the Challenge of Reflexivity,” History and Theory 45 (2006). 


\section{A (Dis)Entangled History of Socialist Encounters between Africa and the GDR}

\section{The Dual Impulses of Decolonization and the German Division: Bandung and Hallstein in the 1950s}

The establishment of the GDR in 1949 provided a zero point for the emergence of new ties between East Germany and the African continent. However, the new state was only nominally independent of the Soviet Union and remained closely tied to Stalinist policies in which the colonial world was seen as an appendage of the imperial powers. Consequently, early contacts in diplomacy, trade, and education did not, for the time being, translate into steady flows of persons, goods or ideas between Africa and the GDR. Egyptian efforts to market their cotton behind the Iron Curtain, as for example when they sent a trade delegation to East Berlin in 1950, were guided by economic concerns and accompanied by resolutely pragmatic and nationalist rhetoric. ${ }^{65}$ Similarly, the arrival of 11 Nigerian trade unionists in 1951, the first non-European students in GDR classrooms, did not immediately lead to more intense exchanges with African countries, most of which were still colonial territories at the time. ${ }^{66}$ The GDR's internationalism expanded beyond Europe during the early 1950s, but the expansion - involving an increasingly dense web of economic relations, the sending of experts, and the intake of students - remained largely confined to the fraternal communist parts of the world, most notably China and North Korea. ${ }^{67}$ Two external impulses lent new diplomatic importance to the Global South. These were West Germany's Hallstein Doctrine, which from 1955 onwards sought to isolate the GDR internationally, and the Bandung moment, also in 1955.

65 See Depta and Hartmetz, this volume; Werner Kilian, Die Hallstein-Doktrin: Der diplomatische Krieg zwischen der BRD und der DDR 1955-1973: aus den Akten der beiden deutschen Außenministerien (Berlin: Duncker \& Humblot, 2001), 104-108. For a broader survey, see Anne-Kristin Hartmetz, Bence Kocsev and Jan Zofka, "East-South Relations during the Global Cold War: Economic Activities and Area Studies Interests of East Central European CMEA Countries in Africa," Working Paper Series of the Collaborative Research Center (SFB) 1199 at the University of Leipzig 11 (2018).

66 Sara Pugach, "Eleven Nigerian Students in Cold War East Germany: Visions of Science, Modernity, and Decolonization”, Journal of Contemporary History 54 (2019).

67 Hong, Cold War Germany, chapter 2; Tao Chen, "Weathering the Storms: East German Engineers in Zhengzhou,1954-1964,” The China Review 19 (2019). 
The 1955 Bandung conference in Indonesia was an important stimulus for anti-imperialist sentiments across the colonial and postcolonial world. ${ }^{68}$ The ideas expressed at the conference were not new, but as Africans across the continent re-emphasized their right for self-government, their importance came to the fore. Despite the initial opportunities for temporary moorings, the institutionalization of South-East links between Africans and East Germans faced serious blockages. Among these obstacles were the colonial powers, who with their anti-communist agendas aimed to keep communist representatives and subversive literature from entering their territories. ${ }^{69}$ Anti-communist sentiment was widespread among African educated elites, at least partially a result of colonial and missionaries' education programs. This too hampered contact. ${ }^{70}$ Many freedom fighters and students, however, were willing to engage with the communist world to acquire symbolic, material and military resources for liberation struggles and opportunities for education, in some cases also actively searching alternatives to neocolonialism. ${ }^{71}$ Contacts with the GDR were often established in the few African countries that were already independent and took an anti-imperialist stand. Cairo and Accra emerged as hubs of decolonization and served, like Conakry or (slightly later) Dar es Salaam and Algiers, as transregional meeting points for Africans from all over the continent and as points of transit to the state socialist countries in Europe. ${ }^{72}$ Circumventing the colonial barriers described above, Africans managed to get in touch with representatives of communist countries and migrate to the East. While some traveled to universities, party schools or trade union colleges in Prague and Moscow, others came to moor at

68 Vijay Prashad, The Darker Nations: A People's History of the Third World (New York: The New Press, 2007), 31-50.

69 Frederick Cooper, Decolonization and African Society: The Labor Question in French and British Africa (Cambridge: Cambridge University Press, 1996), 436; Adi, Pan-Africanism, 138-140. 70 Walter Rodney, "Education in Africa and Contemporary Tanzania," in Education and Black Struggle: Notes from the Colonized World, ed. Institute of the Black World (Cambridge: Harvard Educational Review, 1974).

71 Lena Dallywater, Chris Saunders, and Helder Adegar Fonseca, ed., Southern African Liberation Movements and the Global Cold War 'East': Transnational Activism 1960-1990 (Berlin: De Gruyter, 2019); Ilona Schleicher and Hans-Georg Schleicher, Die DDR im südlichen Afrika: Solidarität und Kalter Krieg (Hamburg: Institut für Afrika-Kunde, 1997).

72 Eric Burton, "Hubs of Decolonization: African Liberation Movements and Eastern Connections in Cairo, Accra and Dar es Salaam," in Southern African Liberation Movements and the Global Cold War 'East': Transnational Activism 1960-1990, ed. Lena Dallywater, Helder A. Fonseca and Chris Saunders (Berlin: De Gruyter, 2019); Eric Burton, "Decolonization, the Cold War and Africans' Routes to Overseas Education, 1957-1965," Journal of Global History 15 (2020). See also Bodie, this volume. 
Bernau or Leipzig. ${ }^{73}$ One of the first relatively large groups of Africans (though they were, like Egyptians, mostly seen as “Arabs") in the GDR were Algerians involved in the war against the French (1954-62), who came, classified as "refugees" or "exiles," to undergo vocational training, attain university degrees, and receive medical treatment. ${ }^{74}$

From the GDR's perspective, the early decolonizers of the late 1950s in SubSaharan Africa, such as Guinea and Ghana, were of strategic importance in breaking through the diplomatic and economic isolation which was imposed by the Hallstein Doctrine. ${ }^{75}$ As African anti-colonialism gained momentum in the late 1950s, still with a variety of options for postcolonial visions, the GDR stepped up its efforts to become an active and respected part of the growing anti-colonial world. By establishing trade missions, consulates, and cultural institutions, the GDR undermined the Hallstein Doctrine, but still ultimately failed to win diplomatic recognition anywhere on the continent. ${ }^{76}$ Still, governments and dominant liberation movements or trade unions were the preferred partners. Few parties in Africa embraced communism; those that did, for example in Algeria, Egypt, Senegal, Sudan, and South Africa, soon found themselves persecuted by the nationalist ruling parties, their influence limited by strong religious, ethnic, and linguistic alliances and the absence of a large working class. ${ }^{77}$ Nevertheless, the SED government continued to establish relations with the dominant nationalist movements on the African continent.

73 Eric Burton, "Introduction: Journeys of Education and Struggle: African Mobility in Times of Decolonization and the Cold War," Stichproben: Vienna Journal of African Studies 34 (2018). Regarding military cooperation and training, see Storkmann, Geheime Solidarität.

74 Patrice G. Poutrus, "An den Grenzen des Proletarischen Internationalismus: Algerische Flüchtlinge in der DDR," Zeitschrift für Geschichtswissenschaft 55 (2007).

75 Gareth Winrow, The Foreign Policy of the GDR in Africa (Cambridge: Cambridge University Press, 2009[1990]), 37-46; Hans-Joachim Spanger and Lothar Brock, Die beiden deutschen Staaten in der Dritten Welt: Die Entwicklungspolitik der DDR. Eine Herausforderung für die Bundesrepublik Deutschland? (Opladen: Westdeutscher Verlag, 1987), 164-167.

76 Joachim Scholtyseck, Die Außenpolitik der DDR (München: Oldenbourg, 2003), 25. On the GDR's almost breakthrough to achieve diplomatic recognition in Guinea see Ilona Schleicher, "FDGB-Offensive in Westafrika. Der Gewerkschaftsbund im Jahr Afrikas," in Engagiert für Afrika: Die DDR und Afrika II, ed. Ulrich van der Heyden, Ilona Schleicher and Hans-Georg Schleicher (Münster: Lit, 1994), 83-84. Regarding the struggles over diplomatic recognition in East Africa, see George Roberts, "Press, Propaganda and the German Democratic Republic's Search for Recognition in Tanzania, 1964-72," in Warsaw Pact Intervention in the Third World: Aid and Influence in the Cold War, ed. Phillip E. Muehlenbeck and Natalia Telepneva (London: I. B. Tauris, 2019).

77 Thiam, Mulira, and Wondji, "Africa and the Socialist Countries," 800; Drew, “Communism in Africa”. 


\section{African Decolonization and Pioneering Institutions in the 1960s}

The year 1960 - dubbed the Year of Africa by the United Nations (UN) - was a turning point in East German relations with the African continent. The number of politically independent African countries rose from nine to 26, which made Africa a force to be reckoned with in international forums such as the UN. Africa's first wave of political independence evoked a sense of excitement among leading East German politicians and among functionaries in the GDR's mass organizations who imagined the socialist world system in the 1960s "as a growing, transformative object," with the Global South as a reserve of socialism or "proto-socialist" region. ${ }^{78}$ A public declaration of the national trade union federation Freier Deutscher Gewerkschaftsbund (FDGB) enthusiastically welcomed the development that "[t]he 190 million Africans have now shaken off the colonial yoke," believing that the "great successes of their sacrificial struggles are an expression of the new balance of power on our planet, which is determined by the existence and growth of the enormous socialist world system."79

African anticolonial liberation movements and the "progressive national democracies" on the African continent were now considered crucial allies in the fight against capitalist imperialism. Updating Lenin's merger of proletarian internationalism and anti-imperialism, theoreticians and some political leaders from the GDR and across the socialist world now argued that the unfolding process of decolonization was an integral part of the world's revolutionary transition from capitalism to socialism. ${ }^{80}$ In the euphoric mood of the early 1960s, the expectation was that the support of socialist countries for progressive "young nationstates" would enable their governments to pursue a "non-capitalist way of development," which would eventually meet the "conditions for a socialist revolution."

78 George Bodie, “It Is a Shame We Are Not Neighbours': GDR Tourist Cruises to Cuba, 1961-89,” Journal of Contemporary History (2019): 433.

79 International Relations Department to Warnke, "Erklärung des Präsidiums des FDGB-Bundesvorstandes zum Freiheitskampf der afrikanischen Völker und Gewerkschaften”, Berlin, February 10, 1961, 154, SAPMO-BArch, DY 34/16600.

80 Ernst Hillebrand, Das Afrika-Engagement der DDR (Frankfurt am Main: Peter Lang, 1987); Hans-Georg Schleicher, "Entwicklungszusammenarbeit und Außenpolitik in der DDR: Das Beispiel Afrika," in Entwicklungspolitische Zusammenarbeit in der Bundesrepublik Deutschland und der DDR, ed. Hans-Jörg Bücking (Berlin: Duncker \& Humblot, 1998).

81 H. Amirahmadi, "The Non-Capitalist Way of Development," Review of Radical Political Economics 19 (1987); I. Andreyev, The Noncapitalist Way: Soviet Experience and the Liberated Countries (Moscow: Moscow Progress Publishers, 1977), 65-69, 101-123; Spanger and Brock, Die bei- 
This increased interest in the African world, motivated by pragmatic considerations and visionary ideals alike, stimulated the creation of a number of pioneering institutions in the socialist countries of Eastern Europe that shaped, and were shaped by, relations with Africa. These institutions usually emerged from national motivations, rather than bloc-determined efforts, to become part of and intervene in a shared anti-imperialist world connecting South and East. These included institutes for foreigners at the Fritz Heckert Trade Union College in Bernau (founded in 1959/60) and Leipzig's Karl Marx University, the Institute for International Studies (Institut für Ausländerstudium, established in 1956, renamed the Herder Institute in 1961), and the Committee for Solidarity with the Peoples of Africa (founded in 1960, in 1963 renamed as the Afro-Asian Solidarity Committee). In the field of health, a newly established sub-unit at the Dorothea Erxleben nursing school in Quedlinburg took in its first students from Mali in 1961. It became the GDR's central institution for non-European nurse trainees and students in the health professions. ${ }^{82}$

Due to blocked diplomatic avenues, but also given ideological preferences for working class organizations, trade union relations had a particular significance. The first courses for African and (to a much smaller extent) Asian trade unionists took place first in Leipzig in 1959-60 and were in 1960/61 institutionalized at the Fritz Heckert Trade Union College in Bernau. ${ }^{83}$ As Eric Angermann shows in his contribution to this volume, African participants at the college in Bernau challenged the course contents and institutional set-up of trade union education, although their political demands were quickly diverted. Angermann's micro-historical study looks at the attempts of the African students in Bernau to set up their own Afro-Asian committee to facilitate cultural and political exchange among their co-students. However, as Angermann emphasizes, the trade union college in Bernau was also an institution which connected Africans

den deutschen Staaten, 114-157; Steffi Marung, “The Provocation of Empirical Evidence: Soviet African Studies Between Enthusiasm and Discomfort,” African Identities 16 (2018).

82 Hong, Cold War Germany, 201-212; Stefan Wolter, Für die Kranken ist das Beste gerade gut genug: Klinikum Dorothea Christiane Erxleben GmbH. 100 Jahre Standort Dithfurter Weg (Quedlinburg: Letterado-Verlag, 2007), 265-268. We thank Sebastian Pampuch for the hint to this institution.

83 Eric Angermann, “'Ihr gehört auch zur Avantgarde: Afrikanische Gewerkschafter an der FDGB-Hochschule Fritz Heckert (1961-1963)” (MA thesis, Georg-August-Universität Göttingen, 2018); George Bodie, "Global GDR? Sovereignty, Legitimacy and Decolonization in the German Democratic Republic, 1960-1989” (PhD diss., University College London, 2019), chapter 2. See also Immanuel R. Harisch, “'Mit gewerkschaftlichem Gruß!’ Afrikanische GewerkschafterInnen an der FDGB-Gewerkschaftshochschule Fritz Heckert in der DDR," Stichproben: Vienna Journal of African Studies 43 (2018). 
with each other across imperial and linguistic borders. In this way, the GDR was sometimes experienced as a pan-African rather than "Eastern" space. After all, "the opportunity to meet is better here [...] than in Africa," as one African student put it. ${ }^{84}$ The report of a trade unionist from Ghana, J. A. Osei, who studied in Bernau, is printed in this volume as a primary source annotated by Immanuel R. Harisch. Osei's report points to the shared language of global, anti-Western socialism and visions of socialist modernity.

Another channel to establishing rapport with African audiences and countering Western anti-communist propaganda was through the media. Radio was the best-suited medium for reaching large numbers of people at a fairly low cost. In 1964, Radio Berlin International set up its Africa Service, with broadcasts in European and African languages, with employees from several African countries. ${ }^{85}$ Broadcasters included linguistically-trained graduates of area studies courses. The establishment of area studies in the GDR in fact predated the Bandung moment, due to the initiative of academics in Leipzig who used their ties to Western leftists and who made significant advances in colonial history. ${ }^{86}$ Africans came to the GDR as lecturers and scientific cooperators, providing the groundwork for effective language courses, co-writing dictionaries, and teaching interpreters and diplomats who would travel to Africa. ${ }^{87}$ With the rising interest of the ruling elite, however, African Studies and related disciplines were reorganized in the 1960 s in closer alignment with political aims. ${ }^{88}$ On the other hand, East German lecturers also received invitations to teach and

84 Angermann, this volume.

85 “Comrade Africa,” BBC World Service, Radio Documentary, 53 minutes, November 14, 2019, accessed January 29, 2020, https://www.bbc.co.uk/programmes/w3ct036t. See also Roberts, "Press, Propaganda"; James R. Brennan, "The Cold War Battle Over Global News in East Africa: Decolonization, the Free Flow of Information, and the Media Business, 1960-1980," Journal of Global History 10 (2015).

86 Matthias Middell, "Die Entwicklung der Area Studies in der DDR als Reaktion auf die Dekolonisierungsprozesse der 1950er/1960er Jahre," in Kommunismus jenseits des Eurozentrismus: (= Jahrbuch für Historische Kommunismusforschung 2019), ed. Matthias Middell (Berlin: Metropol, 2019).

87 Examples include Stephan Mhando and Joseph Kasella-Bantu from Tanganyika who were involved in building the good reputation of Leipzig's linguistic scholarship on Swahili and other African languages.

88 Ulrich van der Heyden, Die Afrikawissenschaften in der DDR: Eine akademische Disziplin zwischen Exotik und Exempel. Eine wissenschaftsgeschichtliche Untersuchung (Münster: Lit, 1999); Middell, "Die Entwicklung der Area Studies"; Waltraud Schelkle, "Die Regionalwissenschaften der DDR als Modell einer Entwicklungswissenschaft?," in Wissenschaft und Wiedervereinigung: Asien- und Afrikawissenschaften im Umbruch, ed. Wolf-Hagen Krauth and Ralf Wolz (Berlin: Akademie-Verlag, 1998). 
establish curricula and institutions in newly independent African countries. The renowned (and headstrong) Leipzig historian Walter Markov, for instance, served as the first Director of the History Department at the University of Nsukka in Nigeria - despite the fact that he had been expelled from the SED in 1951 on charges of "Titoism." 89 These multi-directional flows in the education and media sectors were one of the most comprehensive and durable aspects of relations between the GDR and African countries. ${ }^{90}$

Due to its geopolitical position and diplomatic role, Nasser's Egypt had occupied a special role in the GDR's foreign policy considerations throughout the late 1950s and 1960s. In their contribution to this volume, Jörg Depta and AnneKristin Hartmetz demonstrate how actors from both German states strove for hegemony in German language teaching and culture transmission. They focus on the work in Cairo of the West German Goethe Institute and the East German counterinstitution that unofficially became known as the Herder Institute. The competition also enabled Egyptians to exploit these rivalries for their own ends during the maelstrom of the Six-Day War. Language instructors such as those at Cairo's “Herder Institute” exemplified Germans in Africa who combined professional and proto-diplomatic functions. Their encounters and experiences in Cairo, among other places, led to the institutionalization in the GDR of the teaching of German as a foreign language as a tool of foreign policy, before the field was even established in West Germany.

In 1963, the Politburo decided to establish another pioneering institution, the Friendship Brigades (Brigaden der Freundschaft) of the Free German Youth (FDJ). These groups of young East Germans, comparable to Western development volunteers, were explicitly seen as "instruments of foreign policy." "91 From 1964 until the end of the GDR in 1990, the FDJ's Central Council (Zentralrat) detached more than 60 friendship brigades to 26 countries in Africa, Asia, and Latin

89 Walter Markov, Kognak und Königsmörder - Historisch-literarische Miniaturen (Berlin: Aufbau-Verlag, 1979), 117-121; Matthias Middell, "Manfred Kossok: Writing World History in East Germany,” Review (ed. Fernand Braudel Center) 38 (2015).

90 Constantin Katsakioris, "The Soviet Union, Eastern Europe, and Africa in the Cold War: The Educational Ties," Working Paper Series of the Collaborative Research Center (SFB) 1199 at the University of Leipzig 16 (2019); Alexandra Piepiorka, "Exploring 'Socialist Solidarity' in Higher Education: East German Advisors in Post-Independence Mozambique (1975-1992), in Education and Development in Colonial and Postcolonial Africa: Policies, Paradigms, and Entanglements, 1890s-1980s, ed. Damiano Matasci, Miguel B. Jerónimo, and Hugo G. Dores (Cham: Springer Nature, 2019).

91 Eric Burton, “Solidarität und ihre Grenzen: Die 'Brigaden der Freundschaft' der DDR," in Internationale Solidarität: Globales Engagement in der Bundesrepublik und der DDR, ed. Frank Bösch, Caroline Moine, and Stefanie Senger (Göttingen: Wallstein, 2018), 153. 
America. ${ }^{92}$ The first host countries in the 1960s were Mali (1964-79) and Algeria (1964-82), followed by Ghana (1965-66), Guinea (1966 - 85), and Tanzania/Zanzibar (1966-72). ${ }^{93}$ The range of activities was broad: the mostly young and mostly male GDR citizens took up tasks in a spectrum of sectors including industry, agriculture, health services, vocational training, and transport. ${ }^{94}$ While the early brigades' missions in the 1960s were more focused on increasing the GDR's international reputation through various types of aid projects, the late 1970s and 1980s marked a closer alignment of friendship brigades' solidarity projects with East German foreign trade interests, such as the provision of Angolan coffee or a coal mine project in Mozambique. ${ }^{95}$

It was not only the GDR which set up new institutions and channels of exchange. As Christian Alvarado shows in his contribution to this volume, Kenyans studying in the GDR founded new institutions such as the "Kenya Students Union" to navigate the demands of East German authorities, their sending government's mission, and to help students fulfill their personal ambitions to embark on careers in the rapidly expanding Kenyan bureaucracy. Alvarado's comparative analysis of experiences of student unions in the GDR and Yugoslavia highlights how Kenyan student union members pushed against their racialized reception in Europe by campaigning for a "truer" representation of Kenya in film and other media. While GDR authorities encouraged the organization of African students in single unified national organizations, students could always turn out to be "agents of dissent" who shaped and used associations also in their own ways, sometimes across the Iron Curtain, that contrasted and often conflicted with the objectives of both sending and receiving governments. ${ }^{96}$

92 Ulrich van der Heyden, "FDJ-Brigaden der Freundschaft aus der DDR - Die Peace Corps des Ostens?," in Die eine Welt schaffen: Praktiken von "Internationaler Solidarität" und "Internationaler Entwicklung," ed. Berthold Unfried and Eva Himmelstoß, (Leipzig: Akademische Verlagsanstalt, 2012).

93 Ilona Schleicher, "Elemente entwicklungspolitischer Zusammenarbeit in der Tätigkeit von FDGB und FDJ," in Entwicklungspolitische Zusammenarbeit in der Bundesrepublik Deutschland und der DDR, ed. Hans-Jörg Bücking (Berlin: Duncker \& Humblot, 1998), 136-137.

94 FDJ, Abteilung Brigaden der Freundschaft, "Historische Übersicht - 20 Jahre Brigaden der Freundschaft der FDJ”, Berlin, April 1984, 8, cited in Burton, “Solidarität”, 153.

95 Immanuel R. Harisch, "East German Friendship-Brigades and Specialists in Angola: A Socialist Globalization Project in the Global Cold War," in Transregional Connections in the History of East Central Europe, ed. Katja Naumann (Berlin: De Gruyter, forthcoming 2021).

96 Sara Pugach, "Agents of Dissent: African Student Organizations in the German Democratic Republic,” Africa 89 (2019); Quinn Slobodian, "Bandung in Divided Germany: Managing NonAligned Politics in East and West, 1955-63," The Journal of Imperial and Commonwealth History 41 (2013). 
At the same time, several African governments also established institutions to deal with global connectedness and positioning in general, and to deal with relations with socialist countries in particular. Some of these were state or party departments specializing in economic and political contacts, such as the Ghanaian State Committee for Economic Cooperation with the Soviet Union, China, and Eastern European Countries (CECEC). ${ }^{97}$ Educational institutions also used blueprints or personnel from the GDR and other state socialist countries in Eastern Europe. This included both higher education at universities as well as party and trade union colleges, such as the Kwame Nkrumah Ideological Institute in Ghana (1961-66). Another example was Mozambique's Faculty for Former Combatants and Vanguard Workers, which was a variation of the blueprint of the workers' and peasants' faculties which had been established first in the Soviet Union, and later in the GDR, Vietnam, and Cuba. ${ }^{98}$

Yet already during the 1960s, some of these institutions ceased to exist as socialist African leaders such as Ghana's Kwame Nkrumah (1966) or Mali's Modibo Keïta (1968) were toppled by right-wing coups. If one were to come up with a periodization of global socialism from an African perspective, there would be no single 1989 moment to mark the end of socialist projects. Rather, there were multiple ruptures and dead ends as well as numerous fresh attempts to set up socialist polities over more than three decades. Even where there were no abrupt regime changes such as in Ghana or Mali, inflated expectations and structural constraints could easily lead to mutual disappointments in relations between Africans and the GDR. A 1967 publication from East Germany critically noted that African governments tended to economically exploit the inter-German scramble, maximizing gains without giving the GDR the recognition it was due. Ironically, with this the authors were displaying the same self-oriented attitude toward the aid competition of which they were accusing the Africans. At the same time, government leaders such as Abeid Amani Karume of Zanzibar, or Jean-Bédel Bokassa of the Central African Republic, complained about East German failures in providing effective economic aid for the modernization of their countries in the late 1960 s and early 1970s. ${ }^{99}$ As G. Thomas Burgess shows in his contribution to this volume, relations between Zanzibar and East Germany unraveled as quickly as they had emerged. However, they still left consequential

97 Calori et al., "Alternative Globalization?," 1.

98 Gerardo Serra and Frank Gerits, "The Politics of Socialist Education in Ghana: The Kwame Nkrumah Ideological Institute, 1961-1966," Journal of African History 60 (2019), 3, accessed November 25, 2019: Miethe et al., Globalization of an Educational Idea.

99 The publication and opinions of African leaders are discussed in Winrow, The Foreign Policy, $76-77$. 
traces such as housing projects and a powerful security apparatus. Less tangible were the narratives and memories of students, technocrats, and teachers traveling back and forth between South and East. Discussing the novel By the Sea by Zanzibar-born writer Abdulrazak Gurnah, in which one of the main characters goes to the GDR for training, Burgess shows that sojourners could discover not only the unexpected colonial assumptions of East German citizens, but also the rich humanist heritage that lay hidden beneath socialist rhetoric. In this way, new South-East entanglements in the 1950s and 1960s, brought about by visions of socialist cooperation and anti-imperialist alliances, led to the establishment of new institutions and mobilities, unearthed legacies of colonial exploitation and discrimination, but simultaneously showed the barriers to closer or more durable alliance.

\section{Reconfiguring Solidarity in Times of Global Crisis in the 1970s}

Already in the late 1960s, East Germans' enthusiasm for revolution in Africa was waning as attention shifted towards developments in the Middle East, Latin America, and Vietnam. Yet in the mid-1970s, when the Portuguese Empire dissolved, mutual interest increased once more. The chronology of decolonization was highly uneven across the African continent. While most territories ruled by the French, British, and Belgians came to be governed by African politicians by the late 1950s and 1960s, the Portuguese dictatorship under António de Oliveira Salazar and later Marcelo Caetano resisted political decolonization and instead declared the Lusophone territories (Angola, Mozambique, GuineaBissau, Cape Verde, and São Tomé and Príncipe) to be overseas provinces of the mother country, namely Portugal. Another factor in the uneven chronology of decolonization was the large white population in southern Africa. South Rhodesia declared its unilateral independence under white minority rule in 1965 and South African apartheid was firmly entrenched until the late 1980s. African leaders, soldiers, and students of selected national liberation parties enjoyed sympathies and increasing financial support from the socialist camp. The GDR's Solidarity Committee campaigned for African liberation from colonial rule. Leaders from the Angolan MPLA (Movimento Popular de Libertação de Angola), Mozambican FRELIMO (Frente de Libertação de Moçambique), South African ANC (African National Congress), Rhodesia's ZAPU (Zimbabwe African People's Union), and Namibia's SWAPO (South West Africa People's Organisation) were frequent 
guests in East Germany throughout the 1960s, 1970s, and 1980s, often trailed by university students, trainees, and activists. ${ }^{100}$

Given that imagery and iconography strongly shaped the culture of solidarity in the GDR, the role of print media and television in portraying Africa deserves particular attention. Leaders from liberation movements such as FRELIMO had an urgent interest in making their views and struggles known in order to gain legitimacy and get access to resources. In this volume, George Bodie shows how journalist and SED party member Ulrich Makosch depicted Africa as simultaneously close and distant in his writing and documentaries. Relating his wanderings through the bush with the male and female guerilla fighters of FRELIMO, Makosch brought African liberation struggles and testimonies of women's emancipation home to East German living rooms. Bodie challenges the usual assumptions regarding state-led cultures of solidarity in GDR: while Makosch's influence in terms of reaching an East German audience and bolstering the spirit of solidarity was modest, his films and journalism were important weapons in FRELIMO's struggle for international recognition.

The 1970s brought an unprecedented scale of economic and political relations, entailing a mingling of solidarity and commerce. African governments and parties which pursued explicitly Marxist programs, such as in Angola, Mozambique, and Ethiopia, ${ }^{101}$ could count on collaboration with political leaderships in the Soviet Union, Cuba, and the state socialist countries of Europe. For the GDR, connections established during the liberation struggles intensified and new opportunities opened up, as African states and independence movements sought international recognition, political and economic development aid, cultural and educational exchange, and military support. 1979, which marked the thirtieth anniversary of the GDR, represented the high point of Africa-GDR relations. A party and state delegation, led by SED General Secretary Erich Honecker, visited Libya, Angola, Zambia, Mozambique, and São Tomé

100 Hans-Georg Schleicher, "The German Democratic Republic (GDR) in the Liberation Struggle of Southern Africa," in Southern African Liberation Struggles 1960-1994: Contemporaneous Documents Vol. 8, ed. Arnold Temu and Joel das Neves Tembe (Dar es Salaam: Mkuki na Nyota, 2014); Anja Schade, "Solidarität und Alltag der DDR aus der Sicht exilierter Mitglieder des African National Congress," in Internationale Solidarität: Globales Engagement in der Bundesrepublik und der DDR, ed. Frank Bösch, Caroline Moine, and Stefanie Senger (Göttingen: Wallstein, 2018); Pampuch, "Afrikanische Freedom Fighter im Exil der DDR.”

101 Contemporary efforts to grasp these new African varieties of socialism include Carl G. Rosberg and Thomas M. Callaghy, ed., Socialism in Sub-Saharan Africa: A New Assessment (Berkeley: Institute of International Studies, University of California, 1979); David Ottaway and Marina Ottaway, Afrocommunism (New York: Africana Publishers, 1986); Keller and Rothchild, ed., AfroMarxist Regimes. 
and Príncipe. They also met with delegations of SWAPO, the Patriotic Front of Zimbabwe, as well as with the ANC. Angola's MPLA and Mozambique's FRELIMO signed friendship treaties with the GDR, "the first contracts of this kind of the GDR with countries outside the socialist community." ${ }^{102}$ In the eyes of Honecker and other high-ranking East German politicians, echoing the optimistic mood of the early 1960s, Africa was returning to the center of world revolution. As the Politburo's foreign relations operator Hermann Axen proclaimed, "this huge continent is in the process of awakening, departing from colonialist and neocolonialist exploitation to a life of freedom, independence and social progress. The world-historical transition of the peoples from exploitation to socialism has now powerfully gripped the fourth continent. The national and social liberation revolutions have taken firm root in Africa."103

The revived rhetoric of African revolution sugarcoated an important change in South-East relations: an increasing economization and commercialization which resulted from fundamental transformations and shocks in global financial and commodity markets, as well as the constraints of Eastern European consumer societies. ${ }^{104}$ In the case of the GDR, the turn towards economic concerns was also facilitated by the admission of both German states to the United Nations in 1973 after which diplomatic recognition ceased to be the primary objective in foreign affairs. In economic terms, the 1970s witnessed a "new phenomenon of interdependence." ${ }^{105}$ Price trends on global raw material and international capital markets, recessions, inflation, and banking crises had immediate repercussions in various countries in Europe, Africa, Asia, and South America.

Due to their inflexible, planned economies, many state socialist countries in Europe had difficulties in adjusting to this new situation. The GDR was no exception. On top of this, from the early 1970s socialist European states were promising a new consumer-oriented economy. Even in those regimes that were able to

102 Wolfgang Meyer and Freimut Keßner, Kämpfendes Afrika: Begegnungen der Freundschaft und Solidarität (Dresden: Zeit im Bild, 1979). Our Translation.

103 Hermann Axen at the 10th Meeting of the SED Central Committee, April 1979, cited in Meyer and Keßner, Kämpfendes Afrika, Preface. Our translation.

104 Sara Lorenzini, "Comecon and the South in the Years of Détente: A Study on East-South Economic Relations," European Review of History 21 (2014); Anne Dietrich, "Oranges and the New Black: Importing, Provisioning, and Consuming Tropical Fruits and Coffee in the GDR, 1971-89," in The Socialist Good Life: Desire, Development, and Standards of Living in Eastern Europe, ed. Cristofer Scarboro, Diana Mincyte, and Zsuzsa Gille (Bloomington: Indiana University Press, 2020), 104-131.

105 Niall Ferguson, "Crisis, What Crisis? The 1970s and the Shock of the Global," in The Shock of the Global: The 1970s in Perspective, ed. Niall Ferguson et al. (Cambridge: The Belknap Press of Harvard University Press, 2010), 15. 
commit to such expenditure, this required substantial investments into housing and retail and was a costly means to guarantee popular support and maintain a stable political system. ${ }^{106}$ Linked to both of these trends, external indebtedness burdened many such national economies and impelled leaders to act. Accordingly, trade officials in the GDR busily sought alternative sources of hard currency or ways of bypassing the world market. Above all, they had an interest in importing mineral resources, coal, and crude oil. This became particularly acute given the Soviet strategy, implemented with other countries in the Council for Mutual Economic Assistance (Comecon), of adjusting their highly subsidized oil prices to be more in line with the recent market price increases. ${ }^{107}$ Facing skyrocketing world market prices for mineral resources and agricultural commodities like cotton, coffee, and cocoa, the GDR's economic planners intensified the principle of barter trade (Ware-gegen-Ware ${ }^{108}$ ). Their trading partners in Africa received trucks, weapons, turnkey facilities, and agricultural machinery. They also got East German personnel, whose tasks were often related to the GDR's material exports. ${ }^{109}$

Enabling the GDR to receive agricultural and mineral commodities without using precious hard currency, trade with Africa was thus "primarily a matter of the existence of the GDR," as the infamous leader of the GDR's powerful foreign trade section Kommerzielle Koordinierung (KoKo), Alexander Schalck-Golodkowski, put it in 1982. ${ }^{110}$ Schalck-Golodkowski and Günter Mittag, the secretary for economy at the Central Committee of the SED, were the leading actors in the so-called Mittag-Kommission, a high-profile party institution established in December 1977 that came to expand, coordinate, and commercialize the GDR's relations with Africa, Asia, and Latin America. The Mittag-Kommission made use of good party relations and newly institutionalized political alliances with regimes

106 Dietrich, “Oranges and the New Black”, 107-108.

107 Winrow, The Foreign Policy of the GDR, 160.

108 Immanuel R. Harisch, "Handel und Solidarität: Die Beziehungen der DDR mit Angola und São Tomé und Príncipe unter besonderer Berücksichtigung des Austauschs 'Ware-gegen-Ware' ca. 1975-1990" (Master Thesis, University of Vienna, 2018).

109 Anne Dietrich, "Zwischen solidarischem Handel und ungleichem Tausch: Zum Südhandel der DDR am Beispiel des Imports kubanischen Zuckers und äthiopischen Kaffees,” Journal für Entwicklungspolitik 30 (2014), doi:10.20446/JEP-2414-3197-30-3-48; Immanuel R. Harisch, "Bartering Coffee, Cocoa and W50 Trucks: The Trade Relationships of the GDR, Angola and São Tomé in a Comparative Perspective," Global Histories 3 (2017), doi:10.17169/GHSJ.2017.135. 110 Döring, Es geht um unsere Existenz, 13. On “KoKo”, see Matthias Judt, Der Bereich Kommerzielle Koordinierung: Das DDR-Wirtschaftsimperium des Alexander Schalck-Golodkowski. Mythos und Realität (Berlin: Ch. Links, 2013). 
in Africa that embraced Marxism. ${ }^{111}$ Following Ethiopia's 1974 revolution and embrace of Marxism-Leninism, the Derg regime desperately needed weapons to fight the Somali invasion of the Ogaden region and to suppress insurgencies within the country. The GDR seized the opportunity and KoKo's foreign traders, in coordination with the Mittag-Kommission, started to deliver military equipment on the basis of a barter agreement in exchange for badly-needed coffee. ${ }^{112}$

Economic reconfigurations were also a political matter. According to Odd Arne Westad, the 1970s and early 1980s marked an era in which the conflict between the USA and the USSR in the "Third World" reached its climax. ${ }^{113}$ The nonaligned movement, which most African states had joined, continuously expressed its fear of a third world war brought about by nuclear armament. ${ }^{114}$ Proxy wars were fought in the Global South, predominantly in Asia and Africa. In 1975 the United States was forced to withdraw from Vietnam. The end of US involvement there served as a fresh inspiration for revolutionaries in Africa and as a source of hope for peace, freedom, and progress.

South of the rivers Congo and Ruvuma, the late phase of decolonization also brought to power governments proclaiming socialist projects. After the Carnation Revolution of April 1974 and the cessation of the colonial war in Lusophone Africa, new independent nation-states were proclaimed, often accompanied by civil war. During the year 1975, when Angola became independent, the power struggle between the competing liberation movements led to a fierce internationalized tussle for political rule in Luanda. While Cuba and the USSR supplied the MPLA with combat troops and arms ${ }^{115}$ to fight off the invasion of South African troops allied with UNITA (União Nacional para a Independência Total de Angola),

111 Anne Dietrich, “Kaffee in der DDR - 'Ein Politikum ersten Ranges”' in Kaffeewelten: Historische Perspektiven auf eine globale Ware im 20. Jahrhundert, ed. Christiane Berth et al. (Göttingen: Vandenhoeck \& Ruprecht, 2015), 230 -233; Döring, Es geht um unsere Existenz, 44; Harisch, "Bartering Coffee," 56.

112 Anne Dietrich, "Bartering Within and Outside the CMEA: The GDR's Import of Cuban Fruits and Ethiopian Coffee," in Between East and South: Spaces of Interaction in the Globalizing Economy of the Cold War, ed. Anna Calori et al. (Berlin: De Gruyter, 2019), 200 - 201; Dietrich, "Kaffee in der DDR"; Dietrich, "Zwischen solidarischem Handel und ungleichem Tausch"; Berthold Unfried, "Friendship and Education, Coffee and Weapons: Exchanges Between Socialist Ethiopia and the German Democratic Republic,” Northeast African Studies 16 (2016).

113 Westad, The Global Cold War.

114 Prashad, The Poorer Nations.

115 Piero Gleijeses, Visions of Freedom: Havana, Washington, Pretoria and the Struggle for Southern Africa, 1976-1991 (Chapel Hill: The University of North Carolina Press, 2016); Vladimir Shubin, The Hot 'Cold War': The USSR in Southern Africa (London, Scottsville: Pluto Press; University of KwaZulu-Natal Press, 2008). 
the GDR continued to support the friendly MPLA government with solidarity shipments ${ }^{116}$ and an array of experts in the fields of transport, agriculture, and education. ${ }^{117}$ The MPLA leadership made it clear that it would expect "the utmost possible commitment of the socialist community", and that "fast acting of every country is important."118 In the context of the 1977 Sofortprogramm ("immediate program”, set up by high-ranked SED and MPLA party officials, including Angolan President Agostinho Neto) for the recovery of Angola's ailing coffee industry after the Portuguese exodus, a total of 217 GDR citizens, including truck drivers, coffee roasters, civil engineers, and car mechanics, were sent to Angola. ${ }^{119}$ The friendship brigades formed the backbone of this solidarity-trade project, and during the 1980s up to eight friendship brigades (out of a total of 19 worldwide) were active in Angola. ${ }^{120}$

As Paul Sprute argues in his contribution to this volume, the diaries of the friendship brigades, authored collectively during the 1980s, show that the young East Germans saw themselves as modernizers for a socialist Angola in the making. In the schematic portrayals in the diaries, Angolans are firmly attributed the role of thankful beneficiaries of East German actions. Their time in Angola justified the East German order in the minds of Brigadisten since Angola's war-torn economy and society assured them of how much material progress had been achieved in the GDR. Emphasizing technical expertise, Sprute identifies the brigades not as a "politics machine" of the GDR's solidarity discourse (as argued by Toni Weis ${ }^{121}$ ), but rather as pursuing a "humanitarian mission of modernization" within a contest of competing East-West visions of European modernism.

In contrast to governments espousing African socialism during the 1960s and emphasizing non-alignment, the rulers of Ethiopia, Mozambique, and Angola actively encouraged closer ties to the East. This led to a reconfiguration of the global landscape. As Marcia C. Schenck argues, the socialist world seen from

116 Schleicher, "The (GDR) in the Liberation Struggle of Southern Africa," 503-507.

117 Bettina Husemann and Annette Neumann, "DDR - VR Angola: Fakten und Zusammenhänge zur bildungspolitischen Zusammenarbeit von 1975 bis 1989," in Engagiert für Afrika. Die DDR und Afrika II, ed. Ulrich van der Heyden, Ilona Schleicher and Hans-Georg Schleicher (Münster: Lit, 1994).

118 "Bericht über den Arbeitsbesuch des Premierministers der Volksrepublik Angola, Lopo do Nascimento, Mitglied des Politbüros und Sekretär des Zentralkomitees der MPLA-Partei der Arbeit, vom 6. bis 8. Februar 1978 in der DDR", February 10, 1978, 6, SAPMO-BArch, DE 1/57596, cited in Harisch, "East German Friendship-Brigades".

119 Harisch, "East German Friendship-Brigades”; Dietrich, "Kaffee in der DDR”.

120 Schleicher, "Elemente entwicklungspolitischer Zusammenarbeit FDGB und FDJ," 137.

121 Weis, "The Politics Machine." 
some places in Africa became closer: "For some Africans the global rise of socialism flattened the geography and led to Havana, East Berlin, Prague, and Moscow becoming likely destinations for students, workers, politicians, and experts from all over the continent; it was thus more likely that a young Mozambican school child would receive its education in geographically distant Cuba or the GDR than in neighboring South Africa or Rhodesia."122 The plurality of encounters in school and working life - including the establishment of new educational institutions for African students in the Socialist world, the deployment of friendship (SdF) brigades, and the recruiting of contract workers - led to new entanglements between African and Eastern Bloc countries and an intensification of the flow of knowledge and ideas between the "Second" and the "Third" world.

East Germany was particularly active in the area of educational cooperation. For instance, more than 600 Angolan students came to study at institutions of higher learning in East Germany, where they had to negotiate the rigorous academic requirements and strict rules regulating their new East German lives to create spaces that conformed to their expectations of study abroad. ${ }^{123}$ Another well-explored example of cooperation in the education sector was the Friendship School (Schule der Freundschaft, SdF) in Staßfurt, East Germany, which 900 Mozambican school children attended between 1982 and 1989. They were later joined by Namibian children. Officially between the ages of 12 and 14 upon their arrival, the Mozambicans underwent the equivalent of middle and high school and left the GDR with two years of professional training under their belt, leading to certificates as skilled workers, ranging from electrician to cook. ${ }^{124}$

122 Schenck, "Constructing and Deconstructing," 136.

123 Marcia C. Schenck, "Negotiating the German Democratic Republic: Angolan Student Migration During the Cold War, 1976-90,” Africa 89 (2019).

124 Marcia C Schenck, "Small Strangers at the School of Friendship: Memories of Mozambican School Students to the German Democratic Republic," Bulletin of the GHI 15 (2020); Annette Scheunpflug and Jürgen Krause, Die Schule der Freundschaft: Ein Bildungsexperiment in der DDR. Beiträge aus dem Fachbereich Pädagogik der Universität der Bundeswehr Hamburg (Hamburg: Universität der Bundeswehr Hamburg, 2000); Mathias Tullner, "Das Experiment 'Schule der Freundschaft' im Kontext der mosambikanischen Bildungspolitik," in Freundschaftsbande und Beziehungskisten: Die Afrikapolitik der DDR und der BRD gegenüber Mosambik, ed. Hans-Joachim Döring and Uta Rüchel (Frankfurt am Main: Brandes \& Apsel, 2005); Uta Rüchel, ““...auf Deutsch sozialistisch zu denken...' - Mosambikaner in der Schule der Freundschaft,” ed. Die Landesbeauftragte für die Unterlagen des Staatssicherheitsdienstes der ehemaligen DDR in Sachsen-Anhalt, (Magdeburg, JVA Naumburg - Arbeitsverwaltung, 2001); Tanja Müller, Legacies of Socialist Solidarity: East Germany in Mozambique (Lanham: Lexington, 2014). 
Francisca Raposo in this volume takes us with her into her own childhood as she reflects on the insecurity, the misinformation, and the weeks and months of waiting to finally leave Mozambique to become a student at the School of Friendship. In this text the reader is invited to relive the anxious anticipation of a Mozambican girl who, when imagining her future schooling in East Germany, dreamt of an unknown future paradise, unburdened by reality. The text, contextualized by Marcia C. Schenck, ends abruptly with the arrival in the GDR, leaving it up to the reader's imagination as to whether the young girl found what she was looking for once moored in the parallel universe of a boarding school in a tiny East German village.

The idea for the SdF was born in FRELIMO leadership circles at the end of the 1970s. President Samora Machel (1975-86) prioritized professional education to provide the industrializing country with skilled labor in the absence of a professional working class. This was important both ideologically and practically. Not only was the working class the revolutionary class in Marxist-socialist exegesis, but the young People's Republic of Mozambique (PRM) lacked people with professional skills. Despite the revolutionary emphasis on the working class, many Mozambicans - including parents, students, and members of the Mozambican Ministry of Education - did not value vocational training as much as general education and advanced degrees. ${ }^{125}$ East Germany was not the only country to offer education aid to socialist-leaning African countries. Mozambicans also studied at the Isla de la Juventud in Cuba. ${ }^{126}$ Similarly, Angolan workers went to Cuba to work and gain skills and technical training. ${ }^{127}$ About 2,500 Angolan workers also went to East Germany between 1985 and 1990. ${ }^{128}$ Nevertheless, the largest program of skills training was established between the GDR and Mozambique in 1979. This contract labor and training program saw about 22,000 contracts signed until its dissolution at the end of the

125 Tullner, "Das Experiment 'Schule der Freundschaft'," 100.

126 Hauke Dorsch, "Rites of Passage Overseas? On the Sojourn of Mozambican Students and Scholars in Cuba," Africa Spectrum 43 (2008); Christine Hatzky, Kubaner in Angola: Süd-Süd Kooperation und Bildungstransfer 1976-1991 (Berlin: De Gruyter, 2012), 239-245; Michael H. Erisman, Cuba's Foreign Relations in a Post-Soviet World (Gainesville: University Press of Florida, 2002), 100.

127 Christine Hatzky, Cubans in Angola: South-South Cooperation and Transfer of Knowledge, 1976-1991, (Madison: The University of Wisconsin Press, 2015).

128 Paulino José Miguele, "Sobre o mito da solidariedade: Trabalhadores contratados moçambicanos e angolanos na RDA," in Projekt Migration, ed. Kölnischer Kunstverein, Dokumentationszentrum und Museum über Migration in Deutschland, Köln, Institut für Kulturanthropologie und Europäische Ethnologie der Johann Wolfgang-Goethe-Universität Frankfurt/Main, Institut für Theorie der Gestalt (Köln: DuMont, 2005), 817. 
GDR. ${ }^{129}$ As Franziska Rantzsch shows in her contribution, the negotiation process between the GDR and Mozambique did not reinvent the wheel but rather used pre-existing blueprints from prior labor migration schemes to East Germany (such as the Polish or Hungarian migrations). It also drew on labor migration experience of Mozambicans to South African mines. Initially, the negotiation process sought to arrive at an agreement that combined the interests of both countries in the name of a policy of mutual advantage. This goal became less central in the 1980s as the GDR disengaged somewhat from Mozambique due to disenchantment with the ongoing turmoil and lack of developmental progress there, and the contract labor and training program started to morph into a source of cheap labor for the GDR.

Based on oral history interviews with returned workers, Fernando Machava explores in this volume the contract labor migration and its legacies from a Mozambican perspective. His focus lies on the workers' reintegration into Maputo's various suburbs after their mass return in the 1990s. Exploring the impact of the goods the returnees brought home, he argues that they at first were able to support themselves and their families and even assumed the function of role models in their communities. Due to a lack of integration in the formal labor market the dreams and aspirations of many returnees were disappointed and some Madjermanes, as the returned workers became known in Mozambique, turned to protest as a result. These protests are still ongoing, and, as Machava highlights, are not always supported by the population at large. Solidarity as lived experience and policy came with restrictions, then and now.

\section{Limits to Socialist Development in the 1980s}

There were limits to socialist assistance. The East German ideals of anti-imperialist solidarity were challenged by the GDR's growing debt and by dissenting opinions within the heterogenous socialist world on the appropriate scope of socialist development policy. For example, the labor and training programs that were negotiated between the GDR and various countries deteriorated into work programs as numbers rose and training aspects increasingly took a back seat. ${ }^{130}$ But it was not only the GDR's political and economic situation that

129 Eric Allina skillfully examines the political aspects of this labor migration in Eric Allina, “'Neue Menschen' für Mosambik: Erwartungen an und Realität von Vertragsarbeit in der DDR der 1980er-Jahre,” Arbeit, Bewegung, Geschichte: Zeitschrift für Historische Studien 15 (2016). 130 The states from which laborers came to East Germany are listed here with the year of the signature of the bilateral agreements: Poland (1963 und 1971), Hungaria (1967), Vietnam (1973 
influenced economic plans. For instance, the escalation of violence in large parts of Lusophone Africa in the first half of the 1980s significantly influenced the outcomes of bilateral efforts. ${ }^{131}$ In Angola, GDR citizens were repeatedly saved from UNITA attacks by Angolan, Cuban, and Soviet soldiers. In Mozambique, eight East German development workers were murdered in 1984 by the anti-communist Resistência Nacional Moçambicana (RENAMO), which enjoyed financial and logistical support from South Africa and North Atlantic Treaty Organization (NATO) members such as the US and West Germany. ${ }^{132}$ From the early 1980s, the intensifying internationalized destabilization war against the socialist governments in Angola and Mozambique led to an East German disengagement in joint economic projects as security concerns and disillusions with the countries' war-torn economies became paramount. In 1981, Mozambique was refused entry into Comecon as most members saw another "developing country" like Vietnam or Cuba as too much of an economic burden. As Sara Lorenzini has argued, "[t] his event signaled the collapse of the rhetoric of a special East-South solidarity," showing that "[n]ot all Third World countries were equal; not all possessed the right level of development to integrate with the socialist system." 133 Only the GDR clearly advocated for the admission, which illustrates that the so-called Eastern Bloc did not represent a homogenous set of interests and opinions. The GDR had invested in the Mozambican coal mining and textile industries,

and 1980), Algeria (1974), Cuba (1975), Mozambique (1979), Mongolia (1982), Angola (1985), China (1986) und North Korea (1986). See Dennis Kuck, "Für den sozialen Aufbau ihrer Heimat'? Ausländische Vertragsarbeitskräfte in der DDR," in Fremde und Fremd-Sein in der DDR: Zu historischen Ursachen der Fremdenfeindlichkeit in Ostdeutschland, ed. Jan C. Behrends, Thomas Lindenberger und Patrice G. Poutrus (Berlin: Metropol, 2003), 272. The study of these labor programs is most advanced for the Mozambican case. The field of labor migrations to other countries in the Eastern Bloc is still wide open; see for instance Alena K. Alamgir, "From the Field to the Factory Floor: Vietnamese Government's Defense of Migrant Workers' Interests in State-Socialist Czechoslovakia," Journal of Vietnamese Studies 12 (2017); idem, “Socialist Internationalism at Work: Changes in the Czechoslovak-Vietnamese Labor Exchange Program, 1967-89” (PhD diss., Rutgers University, 2014).

131 Westad, Global Cold War, chapter 9.

132 Ulrich van der Heyden, “'Es darf nichts passieren!' Entwicklungspolitisches Engagement der DDR in Mosambik zwischen Solidarität und Risiko,"” in Wir haben Spuren hinterlassen! Die DDR in Mosambik: Erlebnisse, Erfahrungen und Erkenntnisse aus drei Jahrzehnten, ed. Matthias Voß (Münster: Lit, 2005); William Minter, Apartheid's Contras: An Inquiry into the Roots of War in Angola and Mozambique, (Johannesburg: Witwatersrand University Press, 1994).

133 Sara Lorenzini, "The Socialist Camp and the Challenge of Economic Modernization in the Third World," in The Cambridge History of Communism, Volume 2: The Socialist Camp and World Power 1941-1960s, ed. Norman M. Naimark, Silvio Pons, and Sophie Quinn-Judge (Cambridge: Cambridge University Press, 2017). 
and planned to get involved in the development of banana plantations and the construction of a pineapple processing plant in the provinces of Sofala and Zambezia. ${ }^{134}$ This episode is one of many that show how the GDR tried to situate itself as an independent international actor within the socialist camp by adopting a pioneering role in the Global South.

On the ground, East German friendship brigades and technical experts increasingly reached their own personal limits and faced security challenges due to the expansion of the armed conflicts in Angola and Mozambique. In her contribution, Katrin Bahr touches upon the fear and insecurity among East German experts in Mozambique that followed the aforementioned deadly attack on German agricultural experts in the province of Niassa. Focusing on private photographs taken by East Germans in Mozambique in the 1980s, Bahr shows everyday experiences of the experts and their families abroad, oscillating between working life and private sphere, and unmasking European stereotypes about "Africa” and the predominantly white male gaze of the photographers. The contribution highlights how the private photographs differ from official state photographs and provide a deeper insight into life (work and leisure) in Mozambique. Bahr claims that the private pictures also follow the narratives of the representation of Africa in the context of colonialism and colonial structures. Moreover, women were often absent in the discourse of manual aid work abroad when it came to visual representation. Rather, if portrayed in private photographs, women act within the private sphere of child rearing and leisure time.

The changing role of women that was proclaimed by all socialist regimes, and which indeed enabled female emancipation to a certain degree, remained incomplete, as the contributions to this volume demonstrate. Evenia, an 18year-old FRELIMO fighter and instructor, assumed a role of prominent military female leadership and gained prominence as a symbol and image in the book Das Mädchen vom Sambesi ['The Girl from the Zambezi'] by GDR journalist Ulrich Makosch (Bodie, this volume), but her portrait was stylized. In it, she remained apart from other Mozambican women and their varied relationships with the socialist project in Mozambique. The relative absence of women in many of the histories about South-Eastern entanglements points to the gap between the rhetoric and reality of empowerment. Jörg Depta and Anne-Kristin Hartmetz show in their contribution to this volume that Egyptian housewives were considered of "little relevance" for the GDR and therefore not targeted by German language courses at the East German Cultural Institute in Cairo. In the end, it

134 Mission report of the Director General of the foreign trade company AHB Fruchtimex of December 21, 1978, 3-11. SAPMO-BArch, DL1/25504. 
is not that female students, workers, development experts, and cooperators did not exist, but they often took a backseat to male actors in all directions and through all strata of society.

Aside from state actors and government institutions, East German grassroots associations gained more importance during the 1980s. However, they continued to be subjected to highly asymmetrical relationships with state-sponsored aid. These "Third World groups" were mostly rooted in churches and focused on solidarity, for instance with Nicaragua, but also on causes such as the anti-apartheid movement and the situation of students and contract workers in the GDR. As Maria Magdalena Verburg has highlighted, these groups criticized the failures of socialism and objected to the discrepancies between propaganda and the practices of state and party leadership. ${ }^{135}$

Mikhail Gorbachev's policies of glasnost and perestroika aimed to address at least some of the inherent contradictions of state socialist regimes. Gorbachev's reform attempts did not only affect the Soviet Union, but rather prepared the ground for reforms and radical changes, and ended up bringing about the implosion of the socialist camp and the end of the global order that had been established after the Second World War. The GDR government was reluctant to accept the political and economic reforms initiated by Gorbachev's new policy after 1985. Furthermore, the East German leadership was uneasy with regard to the shifting interests of the Soviet Union's foreign policy towards Africa, wishing to maintain its close relations with Mozambique, Angola, and Ethiopia. In a speech held at the 27th CPSU Congress in 1986, Gorbachev emphasized the significance of political solutions to regional conflicts in the Global South, but did not mention Mozambique, Angola, Ethiopia, and other African states. This caused some alarm among the delegates from socialist-leaning states within the region present at the congress, who feared a Soviet withdrawal from political, economic, and military support. ${ }^{136}$

\section{Socialist Disentanglements and Transitions - 1989 onwards}

1989 is an iconic date for the history of the Eastern Bloc but it had global implications. Ulf Engel argues that "1989 was a watershed for the African people, too" because it was “part of a 'critical juncture of globalization' in which spatializa-

135 Maria Magdalena Verburg, Ostdeutsche Dritte-Welt-Gruppen vor und nach 1989/90 (Göttingen: V\&R unipress, 2012).

136 Winrow, The Foreign Policy of the GDR in Africa, 207. 
tions of power [were] renegotiated worldwide." 137 Indeed, the "winds of change," which British Prime Minister Harold Macmillan had famously evoked in Cape Town as many African countries turned to independence in 1960, were once again blowing through the continent in the 1990s. In South Africa, Nelson Mandela was released after 27 years in prison in 1990, President Frederik Willem de Klerk lifted the party ban on the ANC, and together they initiated the "miracle" of the end of apartheid. Among those hailing the miracle were those who had conveniently forgotten that they had supported apartheid as a bulwark against communism. ${ }^{138}$ The same year that Mandela was released from prison, Namibia finally became independent. ${ }^{139}$ In Zimbabwe, Robert Mugabe's oneparty state evolved after the merger of ZANU and ZAPU (Zimbabwe African Peoples Union) to the ZANU-PF (Zimbabwe African National Union - Patriotic Front) on December 22, 1987. ${ }^{140}$ Exactly one year later, in Angola, an - albeit transitory - peace process was initiated with the agreement of December 22, 1988. Cuban and Soviet troops were withdrawn from Africa shortly after. ${ }^{141}$

Overall, in the late 1980s, many regimes across the continent set aside their socialist convictions. Preceded by the implementation of Structural Adjustment Programs (SAPs), financed by the International Monetary Fund (IMF), and following the socialist countries' recommendation to accept Western aid and capital, various African governments began to think of - or surrendered after years of resistance to ${ }^{142}$ - both economic and political reforms and engagement with new political institutions which mostly brought them closer to a globalizing emerging market-based world order. While 1989 was a key moment in East Germany and the Eastern Bloc, heralding rapid political changes that led to the dissolution of the GDR in 1990 and of the Soviet Union in 1991, the search for communist answers went on in Cuba, North Korea, and China. In Africa, as discussed

137 Ulf Engel, “Africa's ‘1989,”’ in 1989 in a Global Perspective, ed. Ulf Engel, Frank Hadler, and Matthias Middell (Leipzig: Leipziger Universitätsverlag, 2015).

138 Patti Ealdmeir, Anatomy of a Miracle: The End of Apartheid and the Birth of the New South Africa (New Brunswick: Rutgers University Press, 1997).

139 Henning Melber, Understanding Namibia: The Trials of Independence (London: Hurst, 2014). 140 Engel, “Africa's '1989',” 334; D.R. Kempton, “Africa in the Age of Perestroika,” Africa Today 38 (1991).

141 Piero Gleijeses, “Moscow’s Proxy? Cuba and Africa 1975-1988," Journal of Cold War Studies 8 (2006).

142 Aili M. Tripp, Changing the Rules: The Politics of Liberalization and the Urban Informal Economy in Tanzania (Berkeley: University of California Press, 1997). For the transformation process of a socialist state in Southern Africa see M. Anne Pitcher, Transforming Mozambique: The Politics of Privatization, 1975-2000 (Cambridge: Cambridge University Press, 2002). 
above, the transition was a more fragmentary and subtle process and did not proceed linearly but extended during the 1980s and early 1990 s.

As made abundantly clear throughout this discussion, neither Africa nor Eastern Europe began to globalize in 1989. However, both regions now joined an exclusively Western-led vision of globalization. In doing so, they abandoned alternative projects. Towards the late 1980s in much of Eastern Europe, democratic transformation and the spread of liberal democracy coincided with the consolidation of capitalist market economies. The impact of the formal disbanding of the Comecon and the Warsaw Pact in June and July 1991 was felt in the Global South. Cuba, for instance, suffered immensely from the resulting economic disintegration, the loss of Eastern European markets, and the abrupt ending of Soviet resource flows. ${ }^{143}$

We should, however, resist the temptation to reify 1989 as the only significant moment of global change. What 1989 confirmed was the end of an alternative vision of global interconnectedness that was grounded in socialist, anti-imperialist geographies. This came to mean the regrouping of Europe under Western domination underlined by the decision of Eastern European countries to seek membership in a Western, "white" world replete with its racialized privileges. So it seemed, at least, from some Global South perspectives. Indeed, Gorbachev's "fateful speech in Finland [...] in which he called for a 'common European home"” sent out "shock waves [that] went through the radical Third World", as the Tanzanian leftist Abdulrahman Babu observed in 1991. In his view, Europe was "returning to its pre-World War One imperial menace - the Europe which has done so much damage to the rest of the world in conquest, slavery, colonization, settlerism, distortion and diversion of our national histories, through the massive devastation of world wars, the depletion of our resources, and the endangering of the world's environment."144 1989 sounded the death knell for cross-continental decolonization aspirations that had already been crumbling. Fortress Europe slowly emerged as Europe integrated and its borders were shifted outwards as new walls and fences were erected southwards in Africa. In the process borders as barriers to mobility solidified as markers of race and a prosperity gap. The Iron Curtain was lifted in 1989 but new walls emerged between Europe and Africa. ${ }^{145}$

143 Anne Dietrich, "Exploring Changes in Cuba's Ports and Hinterlands: Transition from US to Socialist Sugar Markets,” Comparativ 27 (2017): 54.

144 A. M. Babu, “A New Europe: Consequences for Tanzania,” Review of African Political Economy 18 (1991): 75. Parts of the quote are also cited in Mark et al., 1989, 247.

145 See Mark et al., 1989, 9-10. We recognize that the history of European exclusionary borders extends back to the creation of nation states. 
As several of our contributions demonstrate, the end of Eastern European state-socialism and socialist projects in Africa marked a caesura - but not the end - in the multifaceted relations between people that used to live in those countries that once constituted the socialist world. The reverberations of the experiences that migrants from the Global South and the Global East had while navigating complex socialist encounters continue to impact their lives in the present. For instance, the legacies of the socialist period come to life in the biography of an individual former Mozambican contract worker, Ibraimo Alberto, who migrated to the GDR in 1981, witnessed German reunification, and stayed on in unified Germany as a German citizen (Schenck and Alberto). Ibraimo Alberto's experience was both beautiful and heartbreaking, reassuring and discouraging, as he navigated work and boxing in the two Germanies and encountered people who loved him and people who hated him because of his skin color. Xenophobia and racism have become defining features of Ibraimo Alberto's life; first as a constant negative lived experience for him and his family, and today as a topic about which he seeks to raise awareness in Germany. ${ }^{146}$ It is necessary to explicitly state again that racism was always present and a defining feature of the lives of Africans who came to live across the Eastern Bloc. ${ }^{147}$ Though forms of expressions varied across local context, the basic contradiction remained: racist thought and practice permeated the everyday in officially anti-racist and anti-imperialist societies, of which only East Germany had direct historical links to colonialism in Africa. ${ }^{148}$ Racism did not disappear with the end of the socialist republics and unions but in many cases its expression worsened during the hardships of transition and remains an unsolved issue across the formerly socialist world. ${ }^{149}$ The legacies of the socialist encounters explored in this volume

146 Apart from workers African students also suffered from and resided to racism in their daily lives and systemic racism in the SED regime and media in the GDR, see Sara Pugach, "African Students and the Politics of Race and Gender in the German Democratic Republic, 1957-1990," in Comrades of Color: East Germany in the Cold War World, ed. Quinn Slobodian (New York, Oxford: Berghan, 2015).

147 For the context in Czechoslovakia, see Alena K. Alamgir, "Race Is Elsewhere: State-Socialist Ideology and the Racialisation of Vietnamese Workers in Czechoslovakia," Race \& Class 54 (2013). Further, African students in the USSR suffering from racism are a much-explored topic, see for instance Julie Hessler, "Death of an African Student in Moscow: Race, Politics, and the Cold War," Cahiers Du Monde Russe 47 (2006).

148 To understand the workings of racism and socialist chromatism in East Germany see Quinn Slobodian, ed., Comrades of Color.

149 For the East German context, see Patrick R. Ireland, "Socialism, Unification Policy and the Rise of Racism in Eastern Germany," International Migration Review 31 (1997). Eric and Jessica Allina-Pisano explore how racism permeates the lives of African Students in Russia after the 
are complex and the perpetuation of racism and xenophobia in formerly East German states questions the success that international socialist migrations had in provincializing and internationalizing the GDR.

The legacies are also complex on the other side of the globe. Fernando Machava in this volume, for instance, draws out the complicated legacies of the former Mozambican contract workers who returned back to Mozambique in the early 1990s, but whose dreams and aspirations were stifled due to their traumatic reintegration into a Mozambique that remained among the world's poorest states. Back home, the Mozambican returnees from East Germany, whether workers, school students or university students, created their own communities of remembrance, as did Angolan returnees, Vietnamese returnees, and returnees elsewhere. As this volume's emphasis on Mozambique-GDR relations mirrors, the most active continuous interest was expressed by former East German citizens who were sent to Mozambique, by the Mozambican diaspora in Germany and by Mozambicans who went home. This has resulted in an attentiveness, among scholars of African history and Eastern European history alike, vis-à-vis Mozambique. In their contribution Alexandra Piepiorka and Eduardo Buanaissa examine this transcontinental Afro-European memory space from the perspective of historical actors by reading memory literature to explore how the GDR and Mozambique were remembered by Mozambicans who moored in the GDR and East Germans who went to Mozambique during the 1970s and 1980s respectively. The authors focus on the memory of the "other" to explore alternative understandings and lived experiences of socialist exchanges. On the one hand, they introduce individuals like António, a Mozambican student of economics, who bemoaned his disentanglement from East Germans whom he had gotten to know as sociable and friendly in Mozambique but who struck him as impersonal and cold once in the GDR. On the other hand, Dieter, an East German student of Portuguese, felt fully integrated in his dorm at Eduardo Mondlane University in Maputo and became entangled with the lives of his Mozambican fellow students something for which the other East German expats, who generally did not profit as much from private intercultural exchange, envied him. Both António and Dieter were marked by their respective experiences of navigating these cross-continental socialist encounters enough to care about writing down their memories, years later.

transition, see Jessica Allina-Pisano and Eric Allina-Pisano, “Friendship of Peoples’ after the Fall: Violence and Pan-African Community in Post-Soviet Moscow," in Africa in Russia, Russia in Africa: 300 Years of Encounters, ed. Maxim Matusevich (Trenton: Africa World Press, 2007). 
It was not only Mozambican and East German authors who contributed to the new genre of memory literature putting the GDR in a global context. Thomas Kunze and Thomas Vogel have collected stories in their volume "Ostalgie International,"150 which brings together Cuban, Vietnamese, American, Nicaraguan, Namibian, Chilean, Mozambican, Syrian, Angolan, Palestinian, Iraqi, Afghan, Russian, and Mongolian voices who relate their varying memories of the GDR. In Mozambique, the majority of returned contract workers celebrate what Marcia C. Schenck terms "eastalgia" - a nostalgia for aspects of their experience in the GDR which is both similar and quite different in character and expression from the Ostalgie (a portmanteau of the German words for east and nostalgia) felt and expressed by former East German citizens. Many Madjermanes idolize their East German past not least as the carefree time of their youth, but also against the backdrop of their often traumatic reintegration experience in Mozambique, which leaves many struggling in relative poverty today. ${ }^{151}$ Most importantly, public eastalgic remembering serves as criticism of the Mozambican government which has not only failed to achieve a transparent process of the repayment of withheld wages and security benefits from the workers' time in the GDR but also - from the perspective of the workers - has failed to provide stable blue-collar working life and living conditions for what was once intended to be the vanguard workforce of the People's Republic of Mozambique. Experiences collected in the GDR continue to shape how the returnees measure their lives in their home countries. The point of view of socialist cosmopolitans continues to impact the post-socialist landscape.

In sum, this edited volume challenges the view of socialism as marked by stagnation, uniformity, immobility, and isolation by investigating diverse visions and practices of socialism from a global history perspective, pointing out how they shaped - and were shaped in return - by African and European actors in numerous encounters. As illustrated by this book, however, socialist ideas and the encounters they inspired in Africa, Europe, and beyond were not dead ends which have nothing to teach; quite to the contrary, they may act as a constant reminder about the life and death of alternative visions of social, political, and economic organizations and alternative notions of globalization. It is thus a fundamental motivation of this edited volume to provide space for fresh perspectives on South-East encounters in global history and to illustrate the plethora of histori-

150 Thomas Kunze and Thomas Vogel, ed., Ostalgie international: Erinnerungen an die DDR von Nicaragua bis Vietnam (Berlin: Ch. Links, 2010).

151 Marcia C. Schenck, "A Chronology of Nostalgia: Memories of Former Angolan and Mozambican Worker Trainees to East Germany," Labor History 59 (2018). 
cally documented ideas and practices of socialism(s) in Africa and East Germany as seen through encounters of non-elite actors, through examining institution building, and through scrutinizing visions of solidarity. In so doing we shed light on processes of (dis)entanglements, moorings, and unmoorings, and demonstrate that the study of how actors navigated the socialist world is best analyzed from several perspectives, based on multiple archives and framed within global history. This volume, therefore, contributes not only to a more complex understanding of global socialisms as well as Africa's place in the world; it also reveals a panorama of different pasts and, perhaps, futures.

\section{Bibliography}

Adelman, Jeremy. “What Is Global History Now?” Aeon, March 2, 2017. Accessed October 9, 2019. https://aeon.co/essays/is-global-history-still-possible-or-has-it-had-its-moment.

Adi, Hakim. Pan-Africanism: A History. London: Bloomsbury, 2018.

Alamgir, Alena K. "Race Is Elsewhere: State-Socialist Ideology and the Racialization of Vietnamese Workers in Czechoslovakia." Race \& Class 54 (2013): 67-85.

Alamgir, Alena K. "Socialist Internationalism at Work: Changes in the Czechoslovak-Vietnamese Labor Exchange Program, 1967-89.” PhD diss., Rutgers University, 2014.

Alamgir, Alena K. "From the Field to the Factory Floor: Vietnamese Government's Defense of Migrant Workers' Interests in State-Socialist Czechoslovakia." Journal of Vietnamese Studies 12 (2017): $10-43$.

Alamgir, Alena K. "Labor and Labor Migration in State Socialism." Labor History 59 (2018): 271-276.

Alexander, Jocelyn, and JoAnn McGregor. "African Soldiers in the USSR: Oral Histories of ZAPU Intelligence Cadres' Soviet Training, 1964-1979.” Journal of Southern African Studies 43 (2017): 49-66.

Allina, Eric. “'Neue Menschen' für Mosambik: Erwartungen an und Realität von Vertragsarbeit in der DDR der 1980er-Jahre." Arbeit, Bewegung, Geschichte: Zeitschrift für Historische Studien 15 (2016): 65-84.

Allina-Pisano, Jessica, and Eric Allina-Pisano. “'Friendship of Peoples' after the Fall: Violence and Pan-African Community in Post-Soviet Moscow." In Africa in Russia, Russia in Africa: 300 Years of Encounters, edited by Maxim Matusevich, 175-198. Trenton: Africa World Press, 2007.

Allman, Jean. "Phantoms of the Archive: Kwame Nkrumah, a Nazi Pilot Named Hanna, and the Contingencies of Postcolonial History-Writing." The American Historical Review 118 (2013): $104-129$.

Amirahmadi, H. "The Non-Capitalist Way of Development." Review of Radical Political Economics 19 (1987): 22-46.

Andreyev, I. The Noncapitalist Way: Soviet Experience and the Liberated Countries. Moscow: Moscow Progress Publishers, 1977. 
Angermann, Eric. “Ihr gehört auch zur Avantgarde’: Afrikanische Gewerkschafter an der FDGB-Hochschule Fritz Heckert (1961-1963).” Master’s thesis, Georg-August-Universität Göttingen, 2018.

Austen, Ralph A. African Economic History: Internal Development and External Dependency. London: James Currey, 1987.

Babu, A. M. “A New Europe: Consequences for Tanzania." Review of African Political Economy 18 (1991): $75-78$.

BBC World Service, Radio Documentary “Comrade Africa,” November 14, 2019. Last modified January 11, 2020. https://www.bbc.co.uk/programmes/w3ct036 t.

Becker, Joachim. “Anatomie der Sozialismen: Wirtschaft, Staat und Gesellschaft." In Sozialismen: Entwicklungsmodelle von Lenin bis Nyerere, edited by Joachim Becker, and Rudy Weissenbacher, 13-56. Wien: Promedia, 2009.

Bell, Daniel. The Coming of Post-Industrial Society: A Venture in Social Forecasting. New York: Basic Books, 1976.

Bi’bak. “Freundschaft auf Zeit.” Accessed January 11, 2020. https://bi-bak.de/en/bi-bakino/ freundschaft-auf-zeit.

Bockman, Johanna. "Socialist Globalization Against Capitalist Neocolonialism: The Economic Ideas Behind the New International Economic Order." Humanity: An International Journal of Human Rights, Humanitarianism, and Development 6 (2015): 109-128.

Bodie, George. "Global GDR? Sovereignty, Legitimacy and Decolonization in the German Democratic Republic, 1960-1989.” PhD diss., University College London, 2019.

Bodie, George. “'It Is a Shame We Are Not Neighbours': GDR Tourist Cruises to Cuba, 1961-89." Journal of Contemporary History 55 (2020): 411- 434.

Brennan, James R. "The Cold War Battle Over Global News in East Africa: Decolonization, the Free Flow of Information, and the Media Business, 1960-1980." Journal of Global History 10 (2015): $333-356$.

Brizuela-Garcia, Esperanza. "African Historiography and the Crisis of Institutions." In The Study of Africa. Volume 1: Disciplinary and Interdisciplinary Encounters, edited by Paul Tiyambe Zeleza, 135-167. Dakar: Codesria, 2006.

Burton, Eric. "Socialisms in Development: Revolution, Divergence and Crisis, 1917-1991." Journal für Entwicklungspolitik 33 (2017): 4-20.

Burton, Eric. "Tansanias 'Afrikanischer Sozialismus' und die Entwicklungspolitik der beiden deutschen Staaten: Akteure, Beziehungen und Handlungsspielräume, 1961-1990.” PhD diss., University of Vienna, 2017.

Burton, Eric. "Introduction: Journeys of Education and Struggle: African Mobility in Times of Decolonization and the Cold War." Stichproben. Vienna Journal of African Studies 18 (2018): 1-17.

Burton, Eric. "Solidarität und ihre Grenzen: Die 'Brigaden der Freundschaft' der DDR." In Internationale Solidarität: Globales Engagement in der Bundesrepublik und der DDR, edited by Frank Bösch, Caroline Moine, and Stefanie Senger, 152-185. Göttingen: Wallstein, 2018.

Burton, Eric. "Hubs of Decolonization: African Liberation Movements and Eastern Connections in Cairo, Accra and Dar es Salaam." In Southern African Liberation Movements and the Global Cold War 'East': Transnational Activism 1960-1990, edited by Lena Dallywater, Helder A. Fonseca, and Chris Saunders, 25-56. Berlin: De Gruyter, 2019. 
Burton, Eric. "Diverging Visions in Revolutionary Spaces: East German Advisers and Revolution from above in Zanzibar, 1964-1970." In Between East and South: Spaces of Interaction in the Globalizing Economy of the Cold War, edited by Anna Calori, Anne-Kristin Hartmetz, Bence Kocsev, James Mark, and Jan Zofka, 85-116. Berlin: De Gruyter, 2019.

Burton, Eric. "Decolonization, the Cold War and Africans' Routes to Overseas Education, 1957-1965." Journal of Global History 15 (2020): 169-191.

Büschel, Hubertus. Hilfe zur Selbsthilfe: Deutsche Entwicklungsarbeit in Afrika 1960-1975. Frankfurt am Main: Campus, 2014.

Calori, Anna, Anne-Kristin Hartmetz, Bence Kocsev, and Jan Zofka. "Alternative Globalization? Spaces and Economic Interactions between the 'Socialist Camp' and the 'Global South'." In Between East and South: Spaces of Interaction in the Globalizing Economy of the Cold War, edited by Anna Calori, Anne-Kristin Hartmetz, Bence Kocsev, James Mark, and Jan Zofka, 1-32. Berlin: De Gruyter, 2019.

Chen, Tao. "Weathering the Storms: East German Engineers in Zhengzhou, 1954-1964." The China Review 19 (2019): 39-64.

Cooper, Frederick. Decolonization and African Society: The Labor Question in French and British Africa. Cambridge: Cambridge University Press, 1996.

Cooper, Frederick. "What Is the Concept of Globalization Good for? An African Historian's Perspective." African Affairs 100 (2001): 189-213.

Cooper, Frederick. "Possibility and Constraint: African Independence in Historical Perspective." The Journal of African History 49 (2008): 167-196.

Cooper, Frederick. Africa in the World: Capitalism, Empire, Nation-State. Cambridge: Harvard University Press, 2014.

Conrad, Sebastian. What Is Global History? Princeton: Princeton University Press, 2016.

Conrad, Sebastian and Shalini Randeria, ed. Jenseits des Eurozentrismus: Postkoloniale Perspektiven in den Geschichts- und Kulturwissenschaften. Frankfurt: Campus Verlag, 2002.

Coulson, Andrew. Tanzania: A Political Economy. Second edition. Oxford: Oxford University Press, 2013.

Dagne, Haile Gabriel. Das entwicklungspolitische Engagement der DDR in Äthiopien: Eine Studie auf der Basis äthiopischer Quellen. Münster: Lit, 2004.

Dallywater, Lena, Chris Saunders, and Helder Adegar Fonseca, ed. Southern African Liberation Movements and the Global Cold War 'East': Transnational Activism 1960-1990. Berlin: De Gruyter, 2019.

Dietrich, Anne. "Zwischen solidarischem Handel und ungleichem Tausch: Zum Südhandel der DDR am Beispiel des Imports kubanischen Zuckers und äthiopischen Kaffees." Journal für Entwicklungspolitik 30 (2014): 48-67.

Dietrich, Anne. “Kaffee in der DDR - 'Ein Politikum ersten Ranges'." In Kaffeewelten: Historische Perspektiven auf eine globale Ware im 20. Jahrhundert, edited by Christiane Berth, Dorothee Wierling, and Volker Wünderich, 225-247. Göttingen: Vandenhoeck \& Ruprecht, 2015.

Dietrich, Anne. "Exploring Changes in Cuba's Ports and Hinterlands: Transition from US to Socialist Sugar Markets." Comparativ 27 (2017): 41-57.

Dietrich, Anne. "Bartering Within and Outside the CMEA: The GDR's Import of Cuban Fruits and Ethiopian Coffee." In Between East and South: Spaces of Interaction in the 
Globalizing Economy of the Cold War, edited by Anna Calori, Anne-Kristin Hartmetz, Bence Kocsev, James Mark, and Jan Zofka, 197-215. Berlin: De Gruyter, 2019.

Dietrich, Anne. "Oranges and the New Black: Importing, Provisioning, and Consuming Tropical Fruits and Coffee in the GDR, 1971-89." In The Socialist Good Life: Desire, Development, and Standards of Living in Eastern Europe, edited by Cristofer Scarboro, Diana Mincyte, and Zsuzsa Gille. Bloomington: Indiana University Press, 2020.

Dorsch, Hauke. "Rites of Passage Overseas? On the Sojourn of Mozambican Students and Scholars in Cuba." Africa Spectrum 43 (2008): 225-244.

Döring, Hans-Joachim. "Es geht um unsere Existenz": Die Politik der DDR gegenüber der Dritten Welt am Beispiel von Mosambik und Äthiopien. Berlin: Ch. Links, 1999.

Döring, Hans-Joachim and Ute Rüchel. Freundschaftsbande und Beziehungskisten: Die Afrikapolitik der DDR und der BRD gegenüber Mosambik. Frankfurt am Main: Brandes \& Apsel, 2005.

Drayton, R., and David Motadel. "Discussion: The Futures of Global History." Journal of Global History 13 (2018): 1-21.

Drew, Allison. "Communism in Africa." In The Oxford Handbook of the History of Communism, edited by Stephen A. Smith, 285-302. Oxford: Oxford University Press, 2014.

Du Bois, W. E. Burghardt. The World and Africa: An Inquiry into the Part Which Africa Has Played in World History. New York: International Publishers, 1965 [1946].

Ealdmeir, Patti. Anatomy of a Miracle: The End of Apartheid and the Birth of the New South Africa. New Brunswick: Rutgers University Press, 1997.

Ellis, Steven. "Writing Histories of Contemporary Africa." Journal of African History 4 (2002): $1-26$.

Engel, Ulf, and Hans-Georg Schleicher, ed. Die beiden deutschen Staaten in Afrika: Zwischen Konkurrenz und Koexistenz, 1949-1990. Hamburg: Institut für Afrika-Kunde, 1998.

Engel, Ulf. “Africa's '1989'.” In 1989 in a Global Perspective, edited by Ulf Engel, Frank Hadler, and Matthias Middell, 331-348. Leipzig: Leipziger Universitätsverlag, 2015.

Engel, Ulf, Matthias Middell, David Simo, and Katja Werthmann. "Africa in the Globalizing World - a Research Agenda." Comparativ 27 (2017): 97-110.

Engerman, David C. "The Second World's Third World." Kritika: Explorations in Russian and Eurasian History 12 (2011): 183-211.

Erisman, Michael H. Cuba's Foreign Relations in a Post-Soviet World. Gainesville: University Press of Florida, 2002.

Ferguson, James. Global Shadows: Africa in the Neoliberal World Order. Durham: Duke University Press, 2006.

Ferguson, Niall. "Crisis, What Crisis? The 1970s and the Shock of the Global." In The Shock of the Global: The 1970s in Perspective, edited by Niall Ferguson, Charles S. Maier, Erez Manela, and Daniel J. Sargent, 1-21. Cambridge: The Belknap Press of Harvard University Press, 2010.

Friedland, William H., and Carl G. Rosberg, ed. African Socialism. Stanford: Stanford University Press, 1964.

Gleijeses, Piero. “Moscow's Proxy? Cuba and Africa 1975-1988." Journal of Cold War Studies 8 (2006): 3-51.

Gleijeses, Piero. Visions of Freedom: Havana, Washington, Pretoria and the Struggle for Southern Africa, 1976-1991. Chapel Hill: The University of North Carolina Press, 2016. 
Hannam, Kevin, Mimi Sheller, and John Urry. "Editorial: Mobilities, Immobilities and Moorings." Mobilities 1 (2006): 1-22. Accessed December 5, 2019. doi:10.1080/17450100500489189.

Harisch, Immanuel R. "Bartering Coffee, Cocoa and W50 Trucks: The Trade Relationships of the GDR, Angola and São Tomé in a Comparative Perspective." Global Histories 3 (2017): 43-60. Accessed October 28, 2019. doi:10.17169/GHSJ.2017.135.

Harisch, Immanuel R. “Handel und Solidarität: Die Beziehungen der DDR mit Angola und São Tomé und Príncipe unter besonderer Berücksichtigung des Austauschs 'Ware-gegen-Ware' ca. 1975-1990." MA thesis, University of Vienna, 2018.

Harisch, Immanuel R. “'Mit gewerkschaftlichem Gruß!' Afrikanische GewerkschafterInnen an der FDGB-Gewerkschaftshochschule Fritz Heckert in der DDR.” Stichproben. Vienna Journal of African Studies 43 (2018): 77-109.

Harisch, Immanuel R. "East German Friendship-Brigades and Specialists in Angola: A Socialist Globalization Project in the Global Cold War," in Transregional Connections in the History of East Central Europe, edited by Katja Naumann. Berlin: De Gruyter, forthcoming 2021.

Hartmetz, Anne-Kristin, Bence Kocsev, and Jan Zofka. "East-South Relations during the Global Cold War: Economic Activities and Area Studies Interests of East Central European CMEA Countries in Africa." Working Paper Series of the Collaborative Research Center (SFB) 1199 at the University of Leipzig 11 (2018).

Hatzky, C. Kubaner in Angola: Süd-Süd Kooperation und Bildungstransfer 1976-1991. Berlin: De Gruyter, 2012.

Hatzky, C. Cubans in Angola: South-South Cooperation and Transfer of Knowledge, 1976-1991. Madison: The University of Wisconsin Press, 2015.

Hessler, Julie. "Death of an African Student in Moscow: Race, Politics, and the Cold War." Cahiers Du Monde Russe 47 (2006): 33-63.

Hillebrand, Ernst. Das Afrika-Engagement der DDR. Frankfurt am Main: Peter Lang, 1987.

Hong, Young-Sun. Cold War Germany, the Third World, and the Global Humanitarian Regime. New York: Cambridge University Press, 2015.

Howell, Jude. "The End of an Era: The Rise and Fall of G.D.R. Aid." Journal of Modern African Studies 32 (1994): 305-328.

Hunt, Lynn. Writing History in the Global Era. New York: Norton, 2014.

Husemann, Bettina, and Annette Neumann. "DDR - VR Angola: Fakten und Zusammenhänge zur bildungspolitischen Zusammenarbeit von 1975 bis 1989." In Engagiert für Afrika: Die DDR und Afrika II, edited by Ulrich van der Heyden, Ilona Schleicher, and Hans-Georg Schleicher, 158-178. Münster: Lit, 1994.

Ireland, Patrick R. "Socialism, Unification Policy and the Rise of Racism in Eastern Germany." International Migration Review 31 (1997): 541-68.

James, C. L. R. A History of Negro Revolt. Chicago: Research Associates School Times Publications, 2004 [1938].

James, Leslie. George Padmore and Decolonization from Below: Pan-Africanism, the Cold War, and the End of Empire. Houndmills: Palgrave Macmillan, 2015.

Judt, Matthias. Der Bereich Kommerzielle Koordinierung: Das DDR-Wirtschaftsimperium des Alexander Schalck-Golodkowski. Mythos und Realität. Berlin: Ch. Links, 2013. 
Katsakioris, Constantin. "African Intellectuals and the Soviet Union: Internationalism, Pan-Africanism, and Negritude During the Years of Decolonization, 1954-1964." Cahiers du Monde Russe 47 (2006): 15-32.

Katsakioris, Constantin. "Transferts Est-Sud: Échanges Éducatifs et Formation de Cadres Africains en Union Soviétique Pendant les Années Soixante.” Outre-mers 94 (2007): 83-106.

Katsakioris, Constantin. "The Lumumba University in Moscow: Higher Education for a SovietThird World Alliance, 1960-91.” Journal of Global History 14 (2019): 281-300.

Katsakioris, Constantin. "The Soviet Union, Eastern Europe, and Africa in the Cold War: The Educational Ties." Working Paper Series of the Collaborative Research Center (SFB) 1199 at the University of Leipzig 16 (2019).

Katsakioris, Constantin. "Students from Portuguese Africa in the Soviet Union, 1960-74: Anti-Colonialism, Education, and the Socialist Alliance." Journal of Contemporary History (2020): 1-14. Accessed August 1, 2020. doi:10.1177/0022009419893739.

Keller, Edmond J., and Donald S. Rothchild, ed. Afro-Marxist Regimes: Ideology and Public Policy. Boulder: Lynne Rienner, 1987.

Kempton, D. R. “Africa in the Age of Perestroika." Africa Today 38 (1991): 7-29.

Kilian, Werner. Die Hallstein-Doktrin: Der diplomatische Krieg zwischen der BRD und der DDR 1955-1973. Aus den Akten der beiden deutschen Außenministerien. Berlin: Duncker \& Humblot, 2001.

Kuck, Dennis: “'Für den sozialen Aufbau ihrer Heimat?' Ausländische Vertragsarbeitskräfte in der DDR.” In Fremde und Fremd-Sein in der DDR: Zu historischen Ursachen der Fremdenfeindlichkeit in Ostdeutschland, edited by Jan C. Behrends, Thomas Lindenberger und Patrice G. Poutrus, 271-281. Berlin: Metropol, 2003.

Kunze, Thomas, and Thomas Vogel, ed. Ostalgie international: Erinnerungen an die DDR von Nicaragua bis Vietnam. Berlin: Ch. Links, 2010.

Lal, Priya. African Socialism in Postcolonial Tanzania: Between the Village and the World. Cambridge: Cambridge University Press, 2015.

Landau, Loren. B. "Communities of Knowledge or Tyrannies of Partnership: Reflections on North-South Research Networks and the Dual Imperative." Journal of Refugee Studies 25 (2012): 555-570.

Lorenzini, Sara. "Comecon and the South in the Years of Détente: A Study on East-South Economic Relations.” European Review of History 21 (2014): 183-199.

Lorenzini, Sara. "The Socialist Camp and the Challenge of Economic Modernization in the Third World." In The Cambridge History of Communism, Volume 2: The Socialist Camp and World Power 1941-1960s, edited by Norman M. Naimark, Silvio Pons, and Sophie Quinn-Judge, 341-363. Cambridge: Cambridge University Press, 2017.

Machado, Pedro. "Repositioning Africa Within the Global." Africa Today 63 (2016): 88-91. Accessed December 8, 2019. doi:10.2979/africatoday.63.2.09.

Mama, A. "Is It Ethical to Study Africa? Preliminary Thoughts on Scholarship and Freedom." African Studies Review 50 (2007): 1-26.

Mamdani, Mahmood. Scholars in the Marketplace: The Dilemmas of Neo-Liberal Reform at Makerere University, 1989-2005. Dakar, Senegal: CODESRIA Council for the Development of Social Science Research in Africa, 2007. 
Mark, James, and Tobias Rupprecht. "The Socialist World in Global History: From Absentee to Victim to Co-Producer." In The Practice of Global History: European Perspectives, edited by Matthias Middell, 81-115. London: Bloomsbury, 2018.

Mark, James, Bogdan lacob, Tobias Rupprecht, and Ljubica Spaskovska. 1989: A Global History of Eastern Europe. Cambridge: Cambridge University Press, 2019.

Mark, James, Artemy M. Kalinovsky, and Steffi Marung, ed. Alternative Globalizations: Eastern Europe and the Postcolonial World. Bloomington: Indiana University Press, 2020.

Markov, Walter. Kognak und Königsmörder: Historisch-Literarische Miniaturen. Berlin: Aufbau-Verlag, 1979.

Marung, Steffi. "The Provocation of Empirical Evidence: Soviet African Studies Between Enthusiasm and Discomfort." African Identities 16 (2018): 176-190.

Marung, Steffi, Uwe Müller, and Stefan Troebst. "Monolith or Experiment? The Bloc as a Spatial Format." In Spatial Formats Under the Global Condition, edited by Matthias Middell and Steffi Marung, 275-309. Berlin: De Gruyter, 2019.

Matusevich, Maxim. ed. Africa in Russia, Russia in Africa: Three Centuries of Encounters. Trenton: Africa World Press, 2000.

Matusevich, Maxim. "Expanding the Boundaries of the Black Atlantic: African Students as Soviet Moderns." Ab Imperio 2012 (2012): 325-350. doi:10.1353/imp.2012.0060.

Melber, Henning. Understanding Namibia: The Trials of Independence. London: Hurst, 2014.

Meyer, Wolfgang, and Freimut Keßner. Kämpfendes Afrika: Begegnungen der Freundschaft und Solidarität. Dresden: Zeit im Bild, 1979.

Middell, Matthias. "Manfred Kossok: Writing World History in East Germany." Review (Fernand Braudel Center) 38 (2015): 41-69.

Middell, Matthias. "Weltgeschichte DDR: Die DDR in globalgeschichtlicher Perspektive." In Die DDR Als Chance: Neue Perspektiven auf ein altes Thema, edited by Ulrich Mählert, 149-156. Berlin: Metropol Verlag, 2016.

Middell, Matthias. "Auf dem Weg zu einer transregionalen Geschichte des Kommunismus." In Kommunismus jenseits des Eurozentrismus: (= Jahrbuch für Historische Kommunismusforschung 2019), edited by Matthias Middell, 1-14. Berlin: Metropol, 2019.

Middell, Matthias. "Die Entwicklung der Area Studies in der DDR als Reaktion auf die Dekolonisierungsprozesse der 1950er/1960er Jahre." In Kommunismus jenseits des Eurozentrismus: (= Jahrbuch für Historische Kommunismusforschung 2019), edited by Matthias Middell, 223-254. Berlin: Metropol, 2019.

Miethe, Ingrid, Tim Kaiser, Tobias Kriele, and Alexandra Piepiorka, Globalization of an Educational Idea: Workers' Faculties in Eastern Germany, Vietnam, Cuba and Mozambique. Berlin: De Gruyter, 2019.

Miguele, P. J. Sobre o mito da solidariedade: Trabalhadores contratados moçambicanos $e$ angolanos na RDA. Projekt Migration. Kölnischer Kunstverein, Dokumentationszentrum und Museum über Migration in Deutschland, Köln, Institut für Kulturanthropologie und Europäische Ethnologie der Johann Wolfgang Goethe Universität Frankfurt/Main, Institut für Theorie der Gestalt, 431-438. Köln: DuMont, 2005.

Milford, Ismay. "More than a Cold War Scholarship: East-Central African Anticolonial Activists, the International Union of Socialist Youth, and the Evasion of the Colonial State (1955-65)." Stichproben. Vienna Journal of African Studies 34 (2018): 19-43. 
Minter, William. Apartheid's Contras. An Inquiry into the Roots of War in Angola and Mozambique. Johannesburg: Witwatersrand University Press, 1994.

Monson, Jamie. Africa's Freedom Railway: How a Chinese Development Project Changed Lives and Livelihoods in Tanzania. Bloomington: Indiana University Press, 2009.

Muehlenbeck, Philip E., and Natalia Telepneva, ed. Warsaw Pact Intervention in the Third World: Aid and Influence in the Cold War. London: I.B. Tauris, 2018.

Müller, Tanja. Legacies of Socialist Solidarity: East Germany in Mozambique. Lanham: Lexington Books, 2014.

Munslow, Barry, ed. Africa: Problems in the Transition to Socialism. London: Zed, 1986.

Nash, Mark, ed. Red Africa: Affective Communities and the Cold War. London: Black Dog Publishing, 2016.

Nkrumah, Kwame. Towards Colonial Freedom: Africa in the Struggle Against World Imperialism. London: Panaf Books, 1979 [1945].

Nyerere, Julius. “Capitalism or Socialism: The Rational Choice.” New Blackfriars 55 (1974): $440-448$.

Olúfẹ́mi, Táiwò. "What Is 'African Studies’? African Scholars, Africanists, and the Production of Knowledge." In Reclaiming the Human Sciences and Humanities Through African Perspectives, Volume 2, edited by Helen Lauer and Kofi Anyidoho, 966-982. Accra: Sub-Saharan Press, 2012.

Osei-Opare, Nana. "Uneasy Comrades: Postcolonial Statecraft, Race, and Citizenship, GhanaSoviet Relations, 1957-1966." Journal of West African History 5 (2019): 85-111.

Ottaway David, and Marina Ottaway. Afrocommunism. New York: Africana Publishers, 1986.

Padmore, George. How Britain Rules Africa. New York: Negro Universities Press, 1969 [1936].

Pampuch, Sebastian. "Afrikanische Freedom Fighter im Exil der DDR: Dekoloniale Wissensbestände einer 'unerwünschten Geschichte'." In Wissen in Bewegung: Migration und Globale Verflechtungen in der Zeitgeschichte seit 1945, edited by Stephanie Zloch, Lars Müller, and Simone Lässig, 321-348. Berlin: De Gruyter, 2018.

Piepiorka, Alexandra. “Exploring 'Socialist Solidarity' in Higher Education: East German Advisors in Post-Independence Mozambique (1975-1992)." In Education and Development in Colonial and Postcolonial Africa: Policies, Paradigms, and Entanglements, 1890s-1980s, edited by Damiano Matasci, Miguel B. Jerónimo, and Hugo G. Dores, 289-318. Cham: Palgrave Macmillan, 2020.

Piesche, Peggy. "Making African Diasporic Pasts Possible: A Retrospective View of the GDR and Its Black (Step)Children." In Remapping Black Germany: New Perspectives on Afro-German History, Politics, and Culture, edited by Sara Lennox, 226-242. Massachusetts: University of Massachusetts Press, 2016.

Pitcher, M. Anne. Transforming Mozambique: The Politics of Privatization, 1975-2000. Cambridge: Cambridge University Press, 2002.

Pitcher, Anne M., and Kelly M. Askew. "African Socialisms and Postsocialisms." Africa 76 (2006): 1-14.

Poutrus, Patrice G. “An den Grenzen des Proletarischen Internationalismus: Algerische Flüchtlinge in der DDR.” Zeitschrift für Geschichtswissenschaft 55 (2007): 162-178.

Prashad, Vijay. The Darker Nations: A People's History of the Third World. New York: The New Press, 2007.

Prashad, Vijay. The Poorer Nations: A Possible History of the Global South. London: Verso, 2014. 
Pugach, Sara. "African Students and the Politics of Race and Gender in the German Democratic Republic, 1957-1990." In Comrades of Color: East Germany in the Cold War World, edited by Quinn Slobodian, 131-156. New York: Berghahn Books, 2015.

Pugach, Sara. "Eleven Nigerian Students in Cold War East Germany: Visions of Science, Modernity, and Decolonization." Journal of Contemporary History 54 (2019): 551-572.

Pugach, Sara. "Agents of Dissent: African Student Organizations in the German Democratic Republic.” Africa 89 (2019): 90-108.

Quest, Matthew. "George Padmore's and C.L.R. James's International African Opinion.” In George Padmore: Pan African Revolutionary, edited by Fitzroy Baptiste and Rupert Lewis, 105-132. Kingston: Ian Randle, 2009.

Roberts, George. "Press, Propaganda and the German Democratic Republic's Search for Recognition in Tanzania, 1964-72." In Warsaw Pact Intervention in the Third World: Aid and Influence in the Cold War, edited by Philip E. Muehlenbeck and Natalia Telepneva, 148-172. London: I. B. Tauris, 2019.

Rodney, Walter. "Education in Africa and Contemporary Tanzania." In Education and Black Struggle: Notes from the Colonized World, edited by Institute of the Black World, 82-99. Cambridge: Harvard Educational Review, 1974.

Rosberg, Carl G., and Thomas M. Callaghy, ed. Socialism in Sub-Saharan Africa: A New Assessment. Berkeley: Institute of International Studies, University of California, 1979.

Rüchel, Ute. “...auf deutsch sozialistisch zu denken..." - Mosambikaner in der Schule der Freundschaft. Magdeburg: JVA Naumburg - Arbeitsverwaltung, 2001.

Rupprecht, Tobias. Soviet Internationalism After Stalin: Interaction and Exchange Between the USSR and Latin America During the Cold War. Cambridge: Cambridge University Press, 2015.

Sanchez-Sibony, Oscar. Red Globalization: The Political Economy of the Soviet Cold War from Stalin to Khrushchev. Cambridge: Cambridge University Press, 2014.

Schade, Anja. "Solidarität und Alltag der DDR aus der Sicht exilierter Mitglieder des African National Congress." In Internationale Solidarität: Globales Engagement in der Bundesrepublik und der DDR, edited by Frank Bösch, Caroline Moine, and Stefanie Senger, 186-208. Göttingen: Wallstein, 2018.

Schelkle, Waltraud. "Die Regionalwissenschaften der DDR als Modell einer Entwicklungswissenschaft?" In Wissenschaft und Wiedervereinigung: Asien- und Afrikawissenschaften im Umbruch, edited by Wolf-Hagen Krauth and Ralf Wolz, 22-92. Berlin: Akademie-Verlag, 1998.

Schenck, Marcia C. "From Luanda and Maputo to Berlin: Uncovering Angolan and Mozambican Migrants' Motives to Move to the German Democratic Republic (1979-1990)." African Economic History 44 (2016): 203-234.

Schenck, Marcia C. "Socialist Solidarities and Their Afterlives: Histories and Memories of Angolan and Mozambican Migrants in the German Democratic Republic, 1975-2015." PhD diss., Princeton University, 2017.

Schenck, Marcia C. "Constructing and Deconstructing the 'Black East' - a Helpful Research Agenda? Research Note.” Stichproben. Vienna Journal of African Studies 34 (2018): 135-152.

Schenck, Marcia C. "A Chronology of Nostalgia: Memories of Former Angolan and Mozambican Worker Trainees to East Germany." Labor History 59 (2018): 352-374. 
Schenck, Marcia C. "Negotiating the German Democratic Republic: Angolan Student Migration During the Cold War, 1976-90.” Africa 89 (2019): 144-166.

Schenck, Marcia C. "Small Strangers at the School of Friendship: Memories of Mozambican School Students to the German Democratic Republic." Bulletin of the GHI 15 (2020): 41-59.

Scheunpflug, Annette, and Jürgen Krause. Die Schule der Freundschaft: Ein Bildungsexperiment in der DDR. Hamburg, Universität der Bundeswehr Hamburg, 2000.

Schleicher, Hans-Georg. "Entwicklungszusammenarbeit und Außenpolitik in der DDR: Das Beispiel Afrika." In Entwicklungspolitische Zusammenarbeit in der Bundesrepublik Deutschland und der DDR, edited by Hans-Jörg Bücking, 95-110. Berlin: Duncker \& Humblot, 1998.

Schleicher, Hans-Georg. "The German Democratic Republic (GDR) in the Liberation Struggle of Southern Africa." In Southern African Liberation Struggles 1960-1994:

Contemporaneous Documents, Vol. 8, edited by Arnold Temu, and Joel das Neves Tembe, 449-561. Dar es Salaam: Mkuki na Nyota, 2014.

Schleicher, llona. "FDGB-Offensive in Westafrika: Der Gewerkschaftsbund im Jahr Afrikas." In Engagiert für Afrika: Die DDR und Afrika II, edited by Ulrich van der Heyden, Ilona Schleicher, and Hans-Georg Schleicher, 82-93. Münster: Lit, 1994.

Schleicher, Ilona. "Elemente entwicklungspolitischer Zusammenarbeit in der Tätigkeit von FDGB und FDJ." In Entwicklungspolitische Zusammenarbeit in der Bundesrepublik Deutschland und der DDR, edited by Hans-Jörg Bücking, 111-138. Berlin: Duncker \& Humblot, 1998.

Schleicher, Ilona, and Hans-Georg Schleicher. Die DDR im südlichen Afrika: Solidarität und Kalter Krieg. Hamburg: Institut für Afrika-Kunde, 1997.

Scholtyseck, Joachim. Die Außenpolitik der DDR. Munich: Oldenbourg, 2003.

Schulz, Brigitte H. Development Policy in the Cold War Era: The Two Germanies and Sub-Saharan Africa, 1960-1985. Münster: Lit, 1995.

Schwenkel, Christina. "Socialist Mobilities: Crossing New Terrains in Vietnamese Migration Histories." Central and Eastern European Migration Review 4 (2015): 13-25.

Serra, Gerardo, and Frank Gerits. "The Politics of Socialist Education in Ghana: The Kwame Nkrumah Ideological Institute, 1961-1966." Journal of African History 60 (2019): 407-428.

Shubin, Vladimir. The Hot 'Cold War': The USSR in Southern Africa. London, Scottsville: Pluto Press, University of KwaZulu-Natal Press, 2008.

Simo, David. "Writing World History in Africa: Opportunities, Constraints and Challenges." In Global History, Globally: Research and Practice Around the World, edited by Sven Beckert, and Dominic Sachsenmaier, 235-250. London: Bloomsbury, 2018.

Skinner, Kate. “West Africa's First Coup: Neo-Colonial and Pan-African Projects in Togo's 'Shadow Archives'." African Studies Review 6 (2019): 1-24.

Slobodian, Quinn, ed. Comrades of Color: East Germany in the Cold War World. New York: Berghahn Books, 2015.

Slobodian, Quinn. "Bandung in Divided Germany: Managing Non-Aligned Politics in East and West, 1955-63." The Journal of Imperial and Commonwealth History 41 (2013): $644-662$.

Smith, Tony. "New Bottles for New Wine: A Pericentric Framework for the Study of the Cold War.” Diplomatic History 24 (2000): 567-591. 
Sonderegger, Arno. "Der Panafrikanismus im 20. Jahrhundert.” In Afrika im 20. Jahrhundert: Geschichte und Gesellschaft, edited by Arno Sonderegger, Ingeborg Grau, and Birgit Englert, 98-116. Wien: Promedia, 2011.

Sonderegger, Arno. "How the Empire Wrote Back: Notes on the Struggle of George Padmore and Kwame Nkrumah." In Kwame Nkrumah 1909-1972: A Controversial African Visionary, edited by Bea Lundt and Christoph Marx, 19-38. Stuttgart: Franz Steiner Verlag, 2016.

Sonderegger, Arno, Ingeborg Grau, and Birgit Englert. "Einleitung: Afrika im 20. Jahrhundert." In Afrika im 20. Jahrhundert: Geschichte und Gesellschaft, edited by Arno Sonderegger, Ingeborg Grau, and Birgit Englert, 9-26. Wien: Promedia, 2011.

Spanger, Hans-Joachim, and Lothar Brock. Die beiden deutschen Staaten in der Dritten Welt: Die Entwicklungspolitik der DDR. Eine Herausforderung für die Bundesrepublik Deutschland? Opladen: Westdeutscher Verlag, 1987.

Speich, Daniel. “The Kenyan Style of 'African Socialism': Developmental Knowledge Claims and the Explanatory Limits of the Cold War." Diplomatic History 33 (2009): 449-466.

Storkmann, Klaus. Geheime Solidarität: Militärbeziehungen und Militärhilfen der DDR in die “Dritte Welt”. Berlin: Ch. Links, 2012.

Sun, Jodie Y. "Historicizing African Socialisms: Kenyan African Socialism, Zambian Humanism, and Communist China's Entanglements." International Journal of African Historical Studies 52 (2019): $349-374$.

Tanganyika African National Union, “Arusha Declaration,” February 5, 1967. Accessed January 29, 2020. www.marxists.org/subject/africa/nyerere/1967/arusha-declaration. htm.

Thiam, Iba De, James Mulira, and Christophe Wondji. "Africa and the Socialist Countries." In Unesco General History of Africa VIII: Africa since 1935, edited by Ali A. Mazrui and Christophe Wondji, 798-828. Paris, Berkeley: Heinemann, University of California Press, 1993.

Tripp, Aili M. Changing the Rules: The Politics of Liberalization and the Urban Informal Economy in Tanzania. Berkeley: University of California Press, 1997.

Tullner, M. "Das Experiment 'Schule der Freundschaft' im Kontext der mosambikanischen Bildungspolitik." In Freundschaftsbande und Beziehungskisten: Die Afrikapolitik der DDR und der BRD gegenüber Mosambik, edited by Hans-Joachim Döring and Uta Rüchel, 100 -109. Frankfurt am Main: Brandes \& Apsel, 2005.

Unfried, Berthold. "Friendship and Education, Coffee and Weapons: Exchanges Between Socialist Ethiopia and the German Democratic Republic." Northeast African Studies 16 (2016): $15-38$.

van der Heyden, Ulrich. Die Afrikawissenschaften in der DDR: Eine akademische Disziplin zwischen Exotik und Exempel. Eine wissenschaftsgeschichtliche Untersuchung. Münster: Lit, 1999.

van der Heyden, Ulrich. "Es darf nichts passieren! Entwicklungspolitisches Engagement der DDR in Mosambik zwischen Solidarität und Risiko." In Wir haben Spuren hinterlassen! Die DDR in Mosambik: Erlebnisse, Erfahrungen und Erkenntnisse aus drei Jahrzehnten, edited by Matthias Voß, 278-313. Münster: Lit, 2005.

van der Heyden, Ulrich. "FDJ-Brigaden der Freundschaft aus der DDR - Die Peace Corps des Ostens?" In Die eine Welt schaffen: Praktiken von "Internationaler Solidarität" und 
“Internationaler Entwicklung”, edited by Berthold Unfried and Eva Himmelstoß, 99-122. Leipzig: Akademische Verlagsanstalt, 2012.

van der Heyden, Ulrich, llona Schleicher, and Hans-Georg Schleicher, ed. Die DDR und Afrika: Zwischen Klassenkampf und neuem Denken. Münster: Lit, 1993.

van der Heyden, Ulrich, Ilona Schleicher, and Hans-Georg Schleicher, ed. Engagiert für Afrika: Die DDR und Afrika II. Münster: Lit, 1994.

van der Heyden, Ulrich, and Franziska Benger, ed. Kalter Krieg in Ostafrika: Die Beziehungen der DDR zu Sansibar und Tansania. Münster: Lit, 2009.

Verburg, Maria Magdalena. Ostdeutsche Dritte-Welt-Gruppen vor und nach 1989/90. Göttingen: Vandenhoeck \& Ruprecht, 2012.

Weis, Toni. "The Politics Machine: On the Concept of 'Solidarity' in East German Support for SWAPO.” Journal of Southern African Studies 37 (2011): 351-367.

Werner, Michael, and Bénédicte Zimmermann. "Beyond Comparison: Histoire Croisée and the Challenge of Reflexivity." History and Theory 45 (2006): 30-50.

Westad, Odd Arne. The Global Cold War: Third World Interventions and the Making of Our Times. Cambridge: Cambridge University Press, 2005.

Winrow, Gareth M. The Foreign Policy of the GDR in Africa. Cambridge: Cambridge University Press, 2009 [1990].

Wolter, Stefan. Für die Kranken ist das Beste gerade gut genug: Klinikum Dorothea Christiane Erxleben GmbH. 100 Jahre Standort Dithfurter Weg. Quedlinburg: Letterado-Verlag, 2007.

Yuzhou Sun, Jodie. "Historicizing African Socialisms: Kenyan African Socialism, Zambian Humanism, and Communist China's Entanglements." International Journal of African Historical Studies 52 (2019): 349-374.

Zalmanovich, Tal. "From Apartheid South Africa to Socialist Budapest and Back: Communism, Race, and Cold War Journeys." Stichproben. Vienna Journal of African Studies 34 (2018): $111-134$. 